\title{
Italy's Image as a Tourism Destination in the Chinese Leisure Traveler Market
}

\author{
Silvia Gravili ${ }^{1} \&$ Pierfelice Rosato ${ }^{1}$ \\ ${ }^{1}$ Department of Management and Economics, University of Salento, Lecce, Italy \\ Correspondence: Silvia Gravili, Department of Management and Economics, University of Salento, Complesso \\ Ecotekne, via per Monteroni, Lecce, Italy. Tel: 39-0832-298-622. E-mail: silvia.gravilif@unisalento.it
}

Received: September 8, 2017 Accepted: September 25, 2017 Online Published: September 30, 2017

doi:10.5539/ijms.v9n5p28 URL: http://doi.org/10.5539/ijms.v9n5p28

\begin{abstract}
This study aims to measure the image of Italy as a tourism destination on the Chinese leisure traveller market. To this end, Echtner \& Ritchie's model (1991) is applied; however, compared to its original formulation, it is implemented with greater consideration of the experiential dimension and potential travel constraints affecting the perception of the range of tourism goods and services on offer. This enables not just a denotative, but also and above all a connotative measurement of the image, thereby reducing the risk of ambiguity in the interpretation of the most significant attributes that emerged during the analysis. Adopting a hypothetical segmentation of the market in question, it was also possible to the elements that act as encouraging and discouraging factors regarding a holiday in Italy are highlight, identifying tailor-made approaches to the construction and promotion/commercialisation of tourism products designed to be attractive to the specific segment of interest.
\end{abstract}

Keywords: destination image measurement, China, DMO, destination management, destination marketing, travel constraints

\section{Introduction}

In the course of the last ten years the Chinese outbound tourism market has seen rapid growth $(+350 \%$, according to data from the China National Tourism Administration-CNTA and AGI China 24), in terms of both development and diversification. In addition, Chinese tourists are now the main big spenders on the global level: it is sufficient to point out that globally in 2013 they spent an average of just over 1,000 euros a head on tax-free purchases, an increase of $20 \%$ on the previous year (Global Blue, 2015).

The higher disposable income and increased leisure time in which to travel; the spread of the Internet, which has increased the accessibility of information on far-away destinations; a rapid process of urbanisation, characterised by a growing interest, on the part of the wealthiest classes, in high-quality products, highly personalised services and experiences perceived as "luxury"; the development of a middle class increasingly eager to travel and get to know foreign countries; and the clear drive by the government to disseminate "small well-being" among broad swathes of the population have all encouraged Chinese citizens to go on journeys outside their national borders with growing frequency. The result has been a profound shift in the reasons for travelling and, in more general terms, the profile of the typical Chinese tourist.

Indeed, whereas in the past travel foreign was undertaken above all for work or to visit family members and/or friends, today the purpose of the journey is to get to know the world. It also satisfies the more personal need for self-affirmation, which is not "vanity" but "assertion of status". Indeed, travel is considered a way of demonstrating one's spending power and thus of consolidating one's prestige back home (Mok \& Iverson, 2000; Guo, Seongseop Kim, \& Timothy, 2007; Xu \& McGehee, 2012).

Today, for Chinese tourists, the choice of destination of a long-range journey seems to depend on five key factors (Andreu, Claver, \& Quer, 2014):

- the intensity of interaction with the local culture, with a special focus on what is "authentic" and "beautiful";

- the ease of access of services in loco, enabling travellers to move around and independently discover the special characteristics of the area; 
- the ability (or rather, from the point of view of Chinese travellers, the right) to be always online, so as to share photographs and opinions on social networks in real time, to keep in contact with relatives and friends, to be kept up-to-date with the main developments in their home country and to make use of automatic translators;

- the length of time required to obtain a visa, which makes it easier to plan journeys for individuals and groups alike;

- the accessibility of the destination itself. Illuminating in this regard is the attention paid to the availability of direct flights, which can maximise the time available and reduce the overall cost of the holiday.

As a result of historic circumstances and cultural affinities, most Chinese tourists, especially when leaving their national borders for the first time, continue to prefer destinations such as Hong Kong, Macao and Pacific Rim countries. However, the number of tourists wishing to travel to Europe (appreciated for its rich historic and cultural heritage) and the United States (considered highly exotic), is enjoying continuous growth, although Australia remains the favoured destination for lovers of natural beauty.

Based on this trajectory, it is essential to develop marketing programs specifically aimed toward the Chinese tourism market, especially for those destinations where the "distance"-meant both geographically and culturally - incurs a challenging place identity, which should be mitigated by highlighting those aspects which set these destinations apart from its competitors and guarantee a memorable experience (Yeoman, Brass, \& McMahon-Beattie, 2007).

Among European states, Italy accounts for $0.52 \%$ of the total Chinese leisure traveller market, while such travellers account for $2.8 \%$ of the total number of foreign visitors entering the country (Embassies/Consulates/ENIT Joint Report, 2015). According to data provided by the China National Tourism Administration, whereas in 2010 Italy was the fourth European country by number of arrivals and presences after France, Germany and Great Britain, in the course of 2011 and 2012 it was the most popular European destination among Chinese tourists.

Although this was an ephemeral victory, considering that in 2013 Italy was narrowly overtaken by France, interest in Italy has remained high, fuelled by the awarding of the Universal Exposition to Milan in 2015, the opening of an Italian Consulate in Chongqing in 2014 and the creation of preferential channels for the release of visas for individual journeys, which led to the rejection rate falling to $2 \%$ (data from ISTAT). Another factor has been the "Divas hit the road" television show, very popular in China among young people (Cesif, 2014).

However, despite this market potential the availability of accurate and reliable data such as perceptions or images Chinese travelers hold about Italy is lacking, which represents an opportunity for the country to gain competitive advantage in the region (Buhalis, 2000).

In fact, since the construct of destination image has been theorized for the first time (Hunt, 1971; Mayo, 1973), only the works of Baloglu \& McCleary (1999), Baloglu \& Mangaloglu (2001), and Okumus \& Yasin (2008) attempted to measure the image of Italy as a destination. However, these studies did not target the Asian market, but rather analyzed Italy in terms of a wider Mediterranean destination, only partially identifying country-specific strategies for strengthening tourism flows within the country.

To address this research gap, the purpose of this paper is to study the image of Italy as a tourist destination among Chinese leisure travellers. Specifically, the objectives are:

- to identify the most significant attributes that establish the image of Italy;

- to highlight the elements that encourage or discourage travel to Italy, by analysing the features, both positive and negative, that are associated with the experience of travel in Italy;

- to segment, on this basis, the market in question, seeking to understand the most distinctive and attractive ways of accessing the tourism product for each specific segment considered.

To this may be added a further consideration: partly due to the significant growth rates, the outbound Chinese tourism market is undergoing rapid diversification. This process poses further challenges for Italian tourism firms, which in the past often approached Chinese tourists with diffidence and poor preparation, not understanding their culture, attitudes and expectations.

In detail, deeper insights on both the experiential dimension in the consumption of the tourist product (Campos, Mendes, Oom do Valle, \& Scott, 2015; Tung \& Ritchie, 2011), and role of the elements that potentially undermine the image of a destination in the perception of leisure travellers (Chen, Chen, \& Okumus, 2013) are required, due to the ability of multisensory stimuli to generate feelings and/or thoughts in the visitors linked to the fulfilment of their dreams (Agapito, Mendes, \& Valle, 2013), and the role of distance in perceiving the tourist 
product (Massara \& Severino, 2013), respectively.

In these terms, the intention of current research is to also expand upon the theoretical framework of tourism destination image measurement (Gallarza, Saura, \& García, 2002; Echtner \& Ritchie, 1991; Beerli \& Martin, 2004; Baloglu \& McCleary, 1999; Ryan \& Cave, 2005), by suggesting new insights into the Echtner \& Ritchie model (1993).

\section{Destination Image in Managerial Literature}

The clearly intangible nature of the concept and the widespread adoption of an interdisciplinary approach have made the theoretical analysis of destination image particularly complex, preventing the adoption of an unequivocal definition. In this regard, consider the following table, which summarises some of the main definitions of "destination image" formulated in the literature.

Table 1. Summary of the main definitions of "destination image" in the international managerial literature

\begin{tabular}{|c|c|}
\hline Author & Definition \\
\hline Hunt (1971) & «Impressions that a person or persons hold about a state in which they do not reside» \\
\hline Lawson e Bond-Bovy (1977) & $\begin{array}{l}\text { «An expression of knowledge, impressions, prejudice, imaginations and emotional } \\
\text { thoughts an individual has of a specific object or place» }\end{array}$ \\
\hline Crompton (1979) & «Sum of beliefs, ideas, and impressions that a person has of a destination» \\
\hline Dichter (1985) & $\begin{array}{l}\text { «An overall or total impression which is formed as a result of the evaluation of individual } \\
\text { attributes which may contain both cognitive and emotional content» }\end{array}$ \\
\hline Phelps (1986) & «Perceptions or impressions of a place» \\
\hline Gartner e Hunt (1987) & «Impressions that a person holds about a state in which he/she does not reside» \\
\hline Fakeye e Crompton (1991) & $\begin{array}{l}\text { «The mental construct developed by a potential tourist on the basis of a few selected } \\
\text { impressions among the flood of total impressions» }\end{array}$ \\
\hline Ecthner e Ritchie (1991) & $\begin{array}{l}\text { «The perceptions of individual destination attributes and the holistic impression made by } \\
\text { the destination» }\end{array}$ \\
\hline Kotler et al. (1993) & $\begin{array}{l}\text { «The sum of beliefs and impression people hold about places. Images represent a } \\
\text { simplification of a large number of association and pieces of information connected with a } \\
\text { place. They are a product of the mind trying to process and pick out essential information } \\
\text { from huge amounts of data about a place» }\end{array}$ \\
\hline Milman e Pizam (1995) & $\begin{array}{l}\text { «A sum total of the images of the individual elements or attributes that make up the } \\
\text { tourism experience» }\end{array}$ \\
\hline MacKay e Fesenmaier (1997) & $\begin{array}{l}\text { «A compilation of beliefs and impressions based on information processing from a variety } \\
\text { of sources over time, resulting in an internally accepted mental construct ... a composite } \\
\text { of various products (attractions) and attributes woven into a total impression» }\end{array}$ \\
\hline Baloglu e McCleary (1999) & $\begin{array}{l}\text { «An individual's mental representation of knowledge, feelings, and global impressions } \\
\text { about a destination» }\end{array}$ \\
\hline Tapachai e Waryszak (2000) & $\begin{array}{l}\text { «Perceptions or impressions of a destination held by tourists with respect to the expected } \\
\text { benefit or consumption values including functional, social, emotional and conditional } \\
\text { benefits of a destination» }\end{array}$ \\
\hline Cai (2002) & «Perceptions about the place as reflected by the associations held in tourist memory» \\
\hline Kim e Richardson (2003) & $\begin{array}{l}\text { «A totality of impressions, beliefs, ideas, expectations, and feelings accumulated toward a } \\
\text { place over time» }\end{array}$ \\
\hline González (2005) & $\begin{array}{l}\text { «The sensual, aesthetic and emotional dimensions of space, }[\ldots] \text { often based on } \\
\text { contradictory emotions» }\end{array}$ \\
\hline Tasci et al. (2007) & $\begin{array}{l}\text { «An interactive system of thoughts, opinions, feelings, visualizations, and intentions } \\
\text { toward a destination» }\end{array}$ \\
\hline Çakmak e Isaac (2012) & $\begin{array}{l}\text { «Simplifications of the complex beliefs, attitudes, impressions and ideas a person has } \\
\text { about a place» }\end{array}$ \\
\hline
\end{tabular}

In addition, it is seen that some studies consider destination image to be a unitary, "gestalt" construct, more than the sum of its parts (Dadgostar \& Isotalo, 1996; Shani \& Wang, 2011). Others (Gartner, 1994; Reynolds \& Guttman, 1984) in contrast see it as a multi-attribute construct, analysing the reciprocal dependencies between the three fundamental components - hierarchically interrelated — of which it is formed (Gallarza et al., 2002; Tasci, Gartner, \& Cavusgil, 2007): cognitive, conative and affective (Fig. 1). 


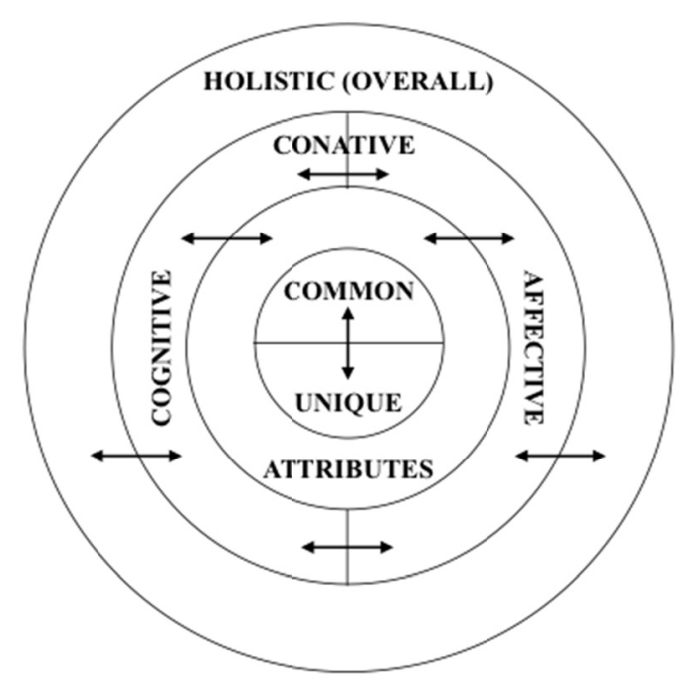

Figure 1. The interactive system of destination image components

Source: Tasci et al., 2007.

In these models, the cognitive dimension refers to the beliefs, knowledge and assessment concerning attributes that are both unique, i.e., specific to the destination, and common, i.e., shared with other competing destinations; the affective dimension includes the complex of sentiments, emotions and desires associated with the destination, which can be positive, negative or neutral; the conative dimension indicates the greater or lesser propensity to visit the destination on the basis of the information possessed and sentiments felt.

Although it can be said in general terms that an increase in the cognitive component entails a greater (Anand, Holbrook, \& Stephens, 1988) and better (Baloglu, 2001) affective propensity towards the destination, it is impossible to establish, a priori, a relationship of cause and effect between the different components of destination image. This is partly because both cognitive and affective responses are linked to environmental stimuli, and partly because the interactions between the three dimensions are characterised by high levels of reciprocity, which makes it necessary to consider each factor not in isolation, but in relation to the others.

Further elements of complexity arise from the fact that by its very nature, tourism destination image (TDI) is intangible (Sevin, 2014); dynamic, because it potentially varies depending on the time and space in which it is measured (Chen, Ji, \& Funk, 2014); relative, because it varies among the different groups of subjects among whom it is measured (Ryan \& Aicken, 2010), as well as frequently being defined by means of comparison with other destinations (Gallarza et al., 2002); and intrinsically fragile, because it is linked on one hand to the uniqueness of the individual experience and on the other to the stereotyped image of the place (Salazar, 2012). 


\begin{tabular}{|c|}
\hline $\begin{array}{c}\text { Cognitive, Affective or/and } \\
\text { conative elements }\end{array}$ \\
Crompton (1979) Stabler (1988)
\end{tabular}

Embacher and Buttle (1989) Gartner (1993)

Balogu and MeCleary (1999) Dann (1996)

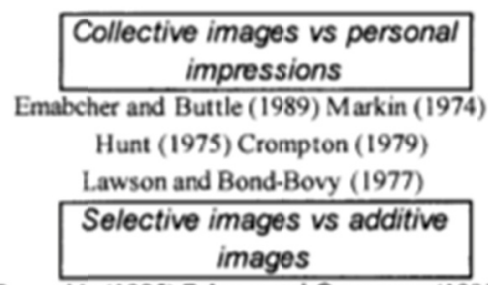

Rey nolds (1985) Fakey e and Crompton (1991)

Crompton (1979) Kotler, Haider and Rein (1994)

$$
\begin{gathered}
\begin{array}{c}
\text { Need of a Multidisciplinary } \\
\text { focus on TDI }
\end{array} \\
\text { Bramwell and Rawding (1996) Baloglu 1997) } \\
\begin{array}{c}
\text { Image as a multi-item } \\
\text { construct or/and as a gestalt }
\end{array} \\
\text { Ahmed (1991,1996) Schroeder (1996) } \\
\text { Baloglu (1997) Carmichacl (1992) } \\
\text { Reilly (1990) Echtner and Ritchie (1991,1993) } \\
\text { Static and Dynamic Structure } \\
\text { of TDI } \\
\text { Hunt (1975) Goodrich (1978) Chon (1990) } \\
\text { Gartner (1993) Baloglu and McCleary (1999) }
\end{gathered}
$$

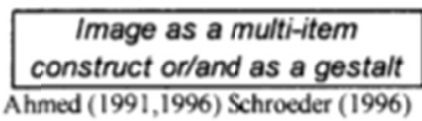

$$
\begin{gathered}
\begin{array}{c}
\text { TDI varies accross people } \\
\text { (segmentation) }
\end{array} \\
\text { A hmed (1996) Baloglu (1997) Crompton (1979) } \\
\text { Fakcye and Crompton (1991) } \\
\text { Schroeder (1996) Sternquist (1985) } \\
\text { TDI involves comparisons } \\
\text { among objects (positioning) }
\end{gathered}
$$

Ahmed (1991) Haahti (1986) Goodrich (1982)

Gartner (1989) Guthrie and Gale (1991)

alantone et al. (1989) Oppermann (1996a, 1996

Crompton et al. (1992)

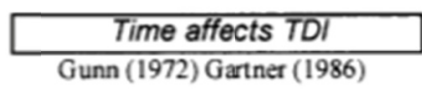

Gartner and Hunt (1987) Selby and Morgan (1996)

Fesenmaier and MaCay (1996)

Distance affects TDI

Crompton (1979) Telisman-Kosuta (1989)

Schroeder (1996) Sternquist (1985)

Legend:

Direct relation Indirect relation

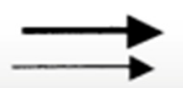

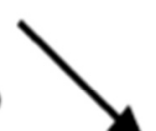

COMPLEX
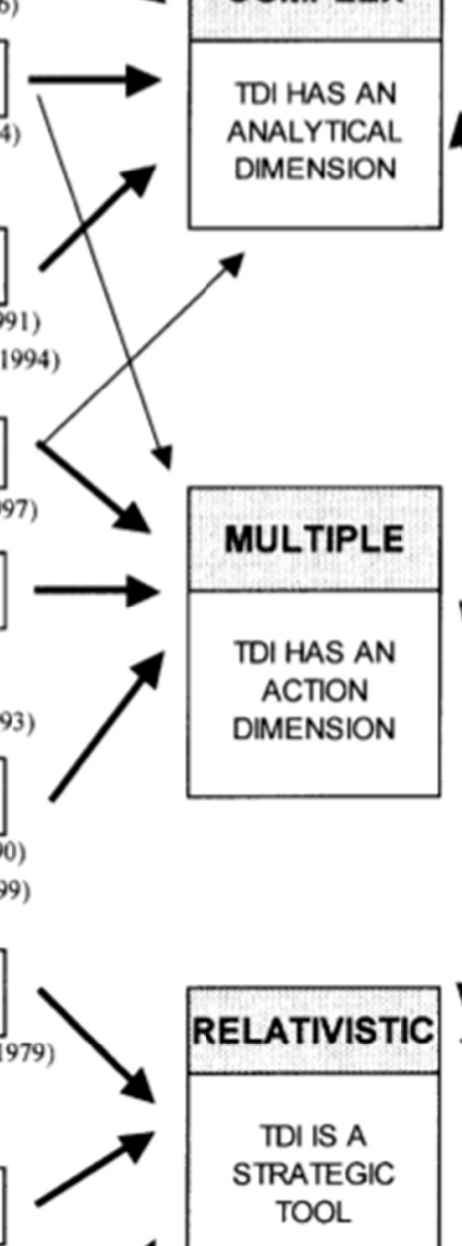

RELATIVISTIC
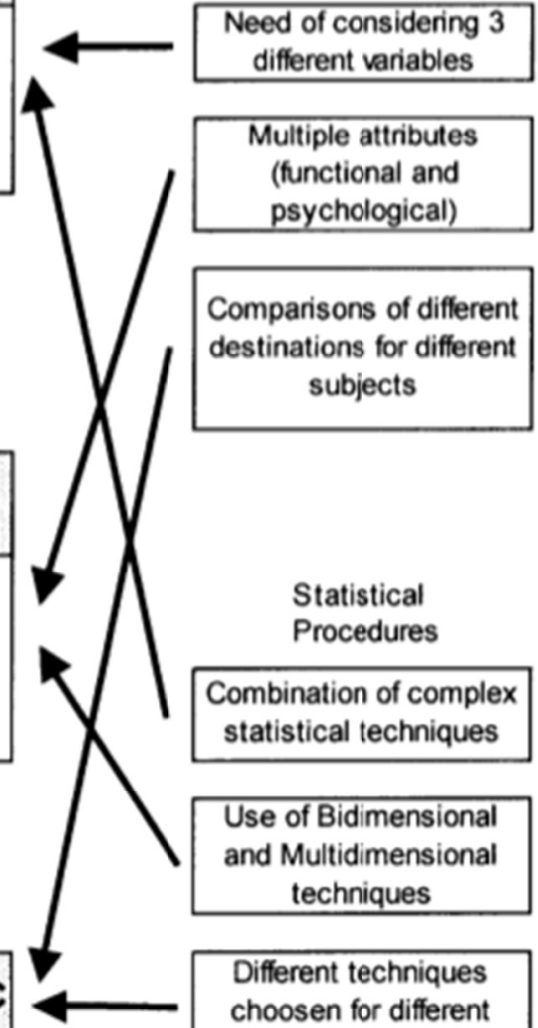

Comparisons of different destinations for different subjects

Statistical

Procedures

Combination of complex statistical techniques

Use of Bidimensional and Multidimensional techniques

Different techniques choosen for different strategic purposes

TDI IS A

STRATEGIC

TOOL

Comparisons Tests among different samples

Figure 2. Main features of the destination image construct

Source: Gallarza et al., 2002. 
Aside from the conceptual nuances however, the scientific literature is united in affirming that the development of a positive and highly distinctive image is crucial in terms of the identification and positioning of a specific tourism destination (Sonmez \& Sirakaya, 2002; Pikkemaat, 2004), since it can affect both its attractiveness (Hu \& Ritchie, 1993; Kozak \& Rimmington, 1999) and the construction of a solid competitive advantage (MacKay \& Fesenmaier, 2000; Uysal, Chen, \& Williams, 2000; Crouch, 2011; Tsai, Song, \& Wong, 2009; Go \& Govers, 2000). In this sense, the image of a destination can have many effects on potential visitors, since:

- it reflects the values, products, services and skills of the various economic actors that operate there (Govers, Go, \& Kumar, 2007), communicating them to the outside world in a unified way (Buhalis, 2000) and incentivising the exchange of resources and skills inside the destination (Haugland, Ness, Grønseth, \& Aarstad, 2011);

- $\quad$ it reduces the perception of risk (Chew \& Jahari, 2014), shapes expectations (Gartner, 1989) and simplifies the large quantity of information available (Kotler, Haider, \& Rein, 1993), providing qualitative guarantees regarding the goods and services offered by the destination and having a positive impact in terms of the cognitive economy of the consumer, helping to mitigate a situation of information overload;

- it guides individual behaviour (Barich \& Kotler, 1990), playing a crucial role in the decisional process of choice and purchase (Hunt, 1975; Pike \& Ryan, 2004; Tapachai \& Waryszak, 2000) when formulating an overall assessment of satisfaction or dissatisfaction with the experience (Veasna, Wu, \& Huang, 2013; Qu, Kim, \& Im., 2011; Oppermann, 2000) and when deciding whether to repurchase and what to tell others (Bigné, Sanchez, \& Sanchez., 2001);

- it consolidates the memory of the experience and reminds the traveller of its most pleasant aspects (Pearce, 1988; Ritchie \& Ritchie, 1998).

\section{Destination Image Measurement: Actual Paradigms and A New Model}

As part of the theoretical framework of tourism destination image measurement (Gallarza et al., 2002; Stepchenkova \& Morrison, 2008; Reilly, 1990; Ryan \& Cave, 2005; Driscoll, Lawson, \& Niven, 1994), for the purposes of the research, the model of Echtner \& Ritchie (1991) was adopted.

This interpretative tool has been extensively used in the international literature (Beerli \& Martìn, 2004; Murphy, Pritchard, \& Smith, 2000; Baloglu \& McCleary, 1999), due to its good reliability, ease of application and ability to combine the advantages of quantitative measurement (Pike, 2002) with those of qualitative analysis (Jenkins, 1999). In addition, the Echtner and Ritchie model enables a unitary representation of the various material and intangible components which, taken together, help define a destination's image. Indeed, the model enriches the measurement with aspects that are apparently of little relevance to the tourism sector (such as the degree of urbanisation and political stability), in the awareness that there are areas of overlap between the constructs of destination image and country image (Richter \& Waugh, 1986; Mossberg \& Kleppe, 2005; Elliot, Papadopoulos, \& Kim, 2011).

This interpretative tool is based on a number of basic observations: first of all, that the image of a destination is the result of the interaction of three fundamental and interrelated components: what an individual knows about a destination (the cognitive component), what an individual feels about it, in terms of impressions, desires, emotions, sentiments, etc. (the affective component) and what an individual recognises as "unique" about it (an aspect that determines the conative component, i.e., his or her actual intention to visit the chosen destination).

Secondly, since the formation of the image is a complex and largely subconscious process, highly conditioned by influences of an environmental kind (linked primarily to internal and external informative stimuli, as well as to the social context of reference) and by subjective factors (linked to the potential traveller's personality, beliefs, memory, previous decisions and individual history), that act and reinforce each other in a process of dynamic and reciprocal exchange, it is not possible to adopt "discrete" parameters of measurement.

Thirdly, when formulating a "verdict" on a destination, the tourist ponders factors of both a material and intangible kind.

The model thus entails the identification of three dimensions, organised along interconnected continuums: Attributes vs. Holistic; Functional vs. Psychological; Common vs. Unique (Fig. 3). 


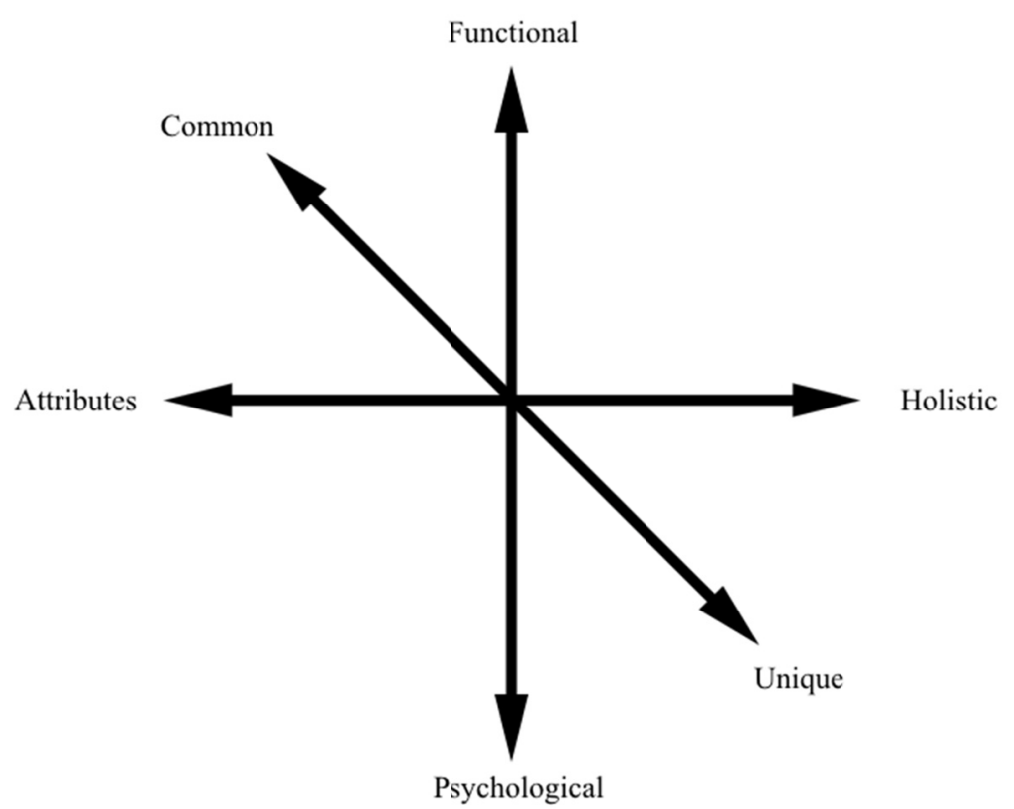

Figure 3. Echtner and Ritchie's model for destination image measurement

Source: Echtner \& Ritchie, 1991.

According to Echtner and Ritchie's conceptual scheme, the image of a destination is not determined solely by the perception of a location's individual characteristics ("attributes"), such as the range of accommodation and catering options, the climate or ease of access, but also by the emotional connection to it, which the individual derives precisely from such attributes. The first opposition (Attributes vs. Holistic) thus lies on a continuum that begins with the identification of the factors that make up the destination-as-product and ends with the analysis of the beliefs that the individual has about that destination.

The fact that some of the attributes are directly observable and/or measurable (for example, the number of museums, restaurants and nightclubs), while others are of a more intangible nature (such as the safety and atmosphere of a place, or the quality of a service) and can therefore be assessed only if viewed in relation to the sensations they arouse in the tourist, determines the next opposition, Functional vs. Psychological.

Lastly, the Common vs. Unique continuum makes it possible to identify a destination's distinctive elements (those that form the basis of its brand awareness), distinguishing them from those considered "common". Individuals refer to these elements, which set the "minimum standards" for a specific target, when comparing one destination with its competitors (for example, its infrastructure, transport, hotel and catering establishments, etc.).

In the implementation of the original model however, we sought to give greater consideration to the experiential dimension in the consumption of the tourist product (Tung \& Ritchie, 2011), in particular via the provision of a series of multisensory stimuli (Agapito et al., 2013) that can generate feelings and/or thoughts in the visitor linked to the fulfilment of their dreams from a highly hedonistic perspective. Indeed, these stimuli are set up by operators within the DMO in the physical (Bitner, 1992), virtual (Li, 2000) and symbolic environments (McClinchey \& Carmichael, 2010), with the goal of acquiring distinctiveness and attractiveness in the various phases of the process of choosing the destination: (i) before the visit itself, to shape desires, aspirations and motives (Lugosi, 2014); (ii) during the visit, to promote interaction between the tourist, other tourists and the human and mechanical components of the destination (Carbone \& Haeckel, 1994), which enables the co-creation of the experience (Prahalad \& Ramaswamy, 2003); (iii) after the visit, to consolidate the memory and to enable the traveller to "relive" the experience (Watson, Morgan, \& Hemmington, 2008) by means of images (Prebensen, 2007) and souvenirs (Ferdinand \& Williams, 2010), and/or by telling stories about the experience online and offline (Moscardo, 2010) to other members of their consumer community (Hsu, Dehuang, \& Woodside, 2009).

In addition, this study sought to clarify in greater detail the role of the elements that potentially undermine the image of a destination in the perception of leisure travellers (Chen, Chen, \& Okumus, 2013). Indeed, there is a risk that in its original formulation the interpretative scheme of Echtner and Ritchie opens the door to ambiguities concerning whether the attributes associated with the destination image confer value or indeed its 
opposite, generating perceptions which act as travel constraints for a particular segment or target (Jackson, 1988). Indeed, researchers have begun to take an interest in the role of such constraints in the overall definition of a destination's image only recently (Chen et al., 2013).

Understood as «factors which preclude or reduce an individual's frequency, rate, or enjoyment as a participant in [tourism/leisure] activities» (Lee, Agarwal, \& Kim, 2012, p. 570), the effect of travel constraints has been studied above all with reference to the decision-making process (Tasci \& Gartner, 2007; Hung \& Petrick, 2012), the search for information (Weinberger, Allen, \& Dillon, 1981; Carneiro \& Crompton, 2010) and the behaviour of tourists affected by physical disabilities (Poria, Reichel, \& Brandt, 2010; Burnett \& Baker, 2001).

These studies display broad convergence with the Leisure Constraint Model of Crawford \& Godbey (1987), who identified three main types of travel constraint: (i) those of a structural nature (such as the destination's climate, the difficulty of reaching it, a lack of information and a shortage of financial resources or time among potential travellers); (ii) those of an interpersonal nature (such as the difficulty of finding a travel companion or unsatisfactory interaction with those responsible for providing the tourism product or service); and (iii) those of an intrapersonal nature (such as stress, depression, anxiety, etc.).

Subsequent studies (Gilbert \& Hudson, 2000; Hinch \& Jackson, 2000; Gladwell \& Bedini, 2004) have however improved the taxonomy of Crawford \& Godbey (1987), pointing out that travel constraints are not insurmountable (Scott, 1991) but are hierarchically ordered. It is argued that the individual must first overcome the intrapersonal obstacles, then those of an interpersonal nature and finally those of a structural nature (Crawford, Jackson, \& Godbey, 1991). In addition, it has emerged that travel constraints act differently depending on the cultural context of reference (Chick \& Dong, 2005; Shinew, Floyd, \& Parry, 2004). Thus, what is considered a potential obstacle by members of one social or national group may not be seen as such by members of another group with a different background. Lastly, for the purposes of the present study, the research has shown that the decision to participate in tourism activities (Um \& Crompton, 1999) and the formulation of an overall positive verdict concerning the enjoyability of the experience (Nadirova \& Jackson, 2000) do not so much require the total absence of constraints as the success of the negotiating process, understood as the «navigation of those obstacles» (Chen, Ji, \& Funk, 2014, p. 199) which enables them to be overcome (Nyaupane $\&$ Andereck, 2008).

Thus, while the greater or lesser incidence of travel constraints depends on the degree to which the potential visitor/tourist is able to minimise their effect, it is clear that a DMO today must develop specific destination marketing policies designed to increase, for each target-segment, the accessibility of information and the degree of familiarity with the destination. Indeed, in this way, it can provide the potential visitor/tourist with the interpretative and/or perceptive keys for managing and thus neutralising factors perceived as obstacles to the complete fulfilment of the holiday. It is clear however that by themselves, such measures are necessary but not sufficient: Indeed, it is essential to conduct a preliminary survey of the factors linked to the destination's attributes that can act as travel constraints and implement adequate destination management policies (such as constant professional training and greater coordination with tourism sector operators) to remove them, above all if they are of a structural nature.

In addition, from studies recently conducted in a managerial context, the relationship between travel constraints and destination image is beginning to be established with greater clarity. In this regard, Chen, Chen \& Okumus (2013) observed a direct inverse correlation between the two constructs, showing that the greater the perception on the part of potential visitors of travel constraints, the less positive the destination image. Conversely, further analyses (Chen, Hua, \& Wang, 2013) have identified the image as one of the most effective means by which to attenuate (and sometimes even neutralise) the negative impact that travel constraints can exert on the actual intention to visit the destination.

Both of these studies lay great emphasis on the negotiation aspect that determines the perception of constraints, as well as on their role - in practice equal to that of attributes and benefits - in the overall definition of a tourist destination's image.

Given these considerations, it would appear to be helpful in this study to integrate travel constraints into Echtner and Ritchie's model as a fourth continuum with which to perform the measurement of the image (Fig. 4). 


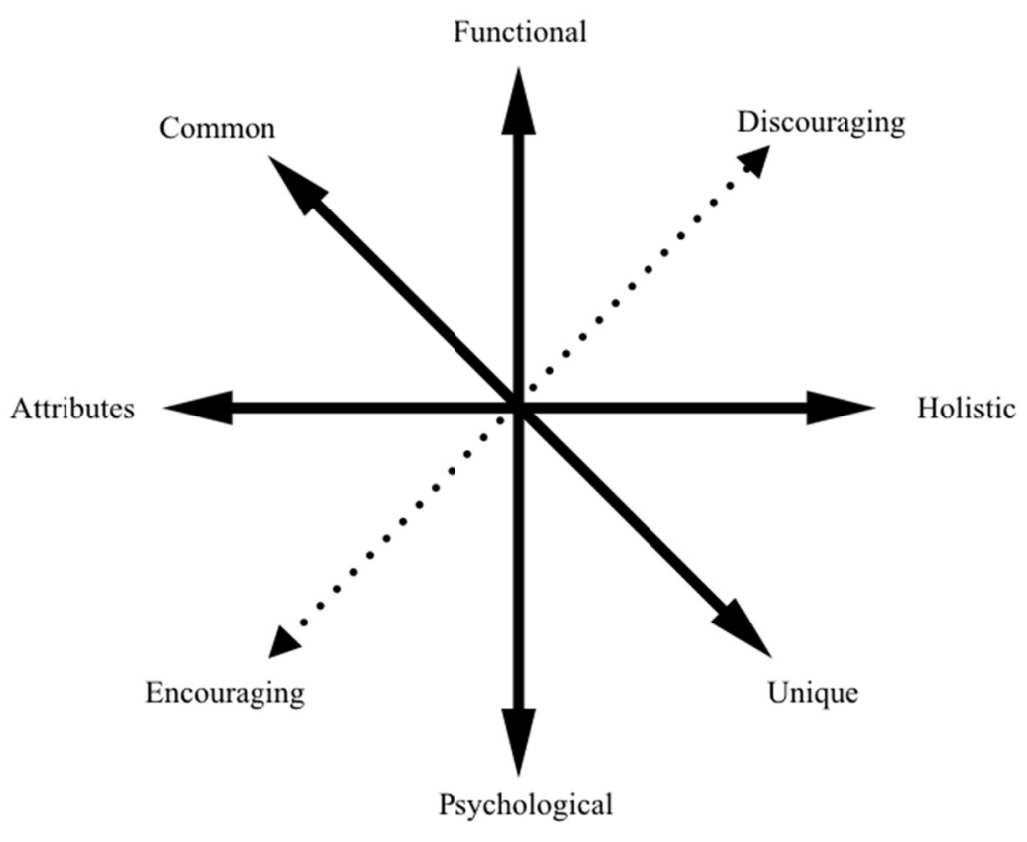

Figure 4. A new model for destination image measurement

In effect, aside from the already-cited negotiation aspect and the different characterisation depending on the context in which they are assessed, there are various areas of contiguity between destination image and travel constraints, to the degree that they may legitimately be considered as two aspects of the same phenomenon (Jackson \& Scott, 1999). We refer here, in the first place, to their dynamic and multidimensional nature (Daniels, Rodgers, \& Wiggins, 2005), as well as to their ability to limit or boost the competitive potential of a tourism destination (Chen et al., 2013).

To be effectively complete then, the measurement of the image must include an assessment of the knowledge and/or perceptions with regard to both desired or desirable experiences and travel constraints, with a view to qualifying the destination's attributes in terms of Encouraging vs. Discouraging. Indeed, it is essential that stakeholders and the heads of DMOs are fully aware of those elements associated with the destination in the eyes of the potential visitor/tourist which are perceived as inhibiting participation in tourist activities or as factors that can negatively affect the overall opinion of the experience. It is only armed with this knowledge that they can jointly adopt - in the strategic planning phase - suitable destination marketing and management measures designed to remove them or-if this is not possible - to limit their reach.

\section{Formulation of the Questionnaire and Operational Methodology}

For the purposes of the research, a semi-structured questionnaire was drawn up in order to identify the main attributes that define the destination image of "Italy" in the Chinese outbound leisure tourism market with reference to the Attributes vs. Holistic, Functional vs. Psychological, Common vs. Unique and Encouraging vs. Discouraging axes. For the selection of the indicators and the formulation of the questions the operational-methodological layout suggested by Echtner \& Ritchie (1991) was adopted.

However, in consideration of the role that distance (understood in both geographical and cultural terms) plays in the definition of the identity of a region (Pizam \& Sussman, 1995; Huang, Chen, \& Lin, 2013), it was decided to partially revise the model, adapting it to cognitive frames that differ from those of Western culture. In this regard, an analysis was performed of the adjectives linked to the description of a place or landscape, as described in Russell \& Pratt (1980), Olsen, Alexander, \& Roberts, (1986), Aaker (1997) and Zube \& Pitt (1981). This was accompanied by an exploratory study designed to detect any misinterpretation of the questions formulated by Echtner \& Ritchie (1991) on the part of "non-western" tourists. This exploratory study was conducted by means of five in-depth interviews with Italian citizens who have lived in China for more than two years and five in-depth interviews with Chinese citizens who have lived in Italy for more than two years.

Thus formulated, the questionnaire was first assessed by a group of experts in themes relating to tourism, marketing and Chinese culture $(\mathrm{N}=3)$. Subsequently a pilot study $(\mathrm{N}=25)$ was performed among the Chinese 
staff of the Galileo Galilei Italian Institute in Chongqing. The feedback obtained made it possible to draw up the definitive list of indicators and questions.

The questionnaire is structured into four parts:

The first was made up of indicators designed to assess the cognitive, affective and conative components of the image of Italy. In addition to the two open-response questions suggested by Echtner \& Ritchie (1991), a wider measurement of the cognitive component of the destination image entailed the addition of two closed-response questions, drawn up on the basis of Boo, Busser, \& Baloglu (2009) and Papadoupolos, Elliot \& De Nisco (2013), in which the respondents were invited to express their degree of agreement by giving a point score from 1 to 5 (where $1=$ totally disagree and $5=$ totally agree). This served to identify the destination resources able to act as factors of distinctiveness and attractiveness with respect to the competitors of reference and measure the brand awareness of the Italian tourism product. Such awareness is held by Milman \& Pizam (1995) to be a crucial prerequisite for the definition of destination brand equity, as well as an essential component of the degree of knowledge of a destination brand, without which the image itself cannot be formed (Keller, 1993; Kotler, Bowen, Makens, Xie, \& Liang, 2006). Moreover, in order to adhere to Chinese frames, the conative component was measured by means of closed-response questions drawn up on the basis of Yoo \& Donthu (2001) and Zeithaml, Berry, \& Parasuraman (1996) concerning their willingness:

- to include Italy in the consideration set

- to recommend a holiday in Italy to relatives and friends.

The second part of the questionnaire entailed the adoption of a 5-point Likert scale as the methodological tool for measuring the attribute-based component, concerning general resources, tourism services and the degree of cultural proximity to the destination. The starting point for the list of attributes was the categorisation proposed by Echtner \& Ritchie (1991). However, considering that every destination has a series of attributes that characterise it specifically and can affect the process of choosing the destination (Pike, 2003), this was enriched with a series of attributes arising from the in-depth interviews conducted previously.

The third part of the questionnaire sought to investigate the experiential dimension of a journey to Italy and to determine Chinese tourists' degree of familiarity with Italy as a tourism destination. In this case too, Echtner \& Ritchie's (1991) original version of the questionnaire was expanded with three open-response questions designed to determine the image of Italy in both positive and negative terms and to identify the main factors that might deter a traveller from going there:

- What five positive words would you use to describe Italy as a vacation destination?

- What five negative words would you use to describe Italy as a vacation destination?

- What are the main disincentives to travelling to Italy?

In order to understand the panorama of expectations linked to a holiday (taking account of competitor destinations), assess any acquisition of greater prestige among the social group of reference following a journey to Italy and obtain an overall judgement concerning a stay in Italy, a 5-point Likert scale was adopted (where $1=$ totally disagree and $5=$ totally agree), with reference to the following statements, drawn up on the basis of Boo et al. (2009) and Pan, Lee, \& Tsai (2014):

- Italy as a tourist destination provides memorable experiences

- I would enjoy visiting Italy

- Italy as a tourist destination is better than other similar destinations

- My friend would think highly of me if I visited Italy

- Overall, Italy is an inviting tourist destination

The fourth part of the questionnaire was designed to determine the socio-demographic profile of the respondents, including gender, age, level of education, family status, profession and annual income.

Considering that in a non-structured questionnaire, the level of detail of the data is closely dependent on the linguistic skills of the respondents, as well as on their willingness to provide complete and articulate responses (McDougall \& Fry, 1974; Stepchenkova \& Morrison, 2008), the questionnaire was distributed in English and Standard Mandarin. The translation of the questions from English into Chinese and the translation of the answers from Chinese into English (Behling \& Law, 2000) was performed with the help of two bilingual Chinese students in order to reduce as much as possible potential semantic ambiguities in both the formulation of the questions and the processing of the answers. The translation process was always performed in two steps: with 
reference to the questionnaire, one student performed the translation from English into Mandarin and another re-translated the result from Mandarin back into English in order to verify that the substance had not changed. Similarly, the answers obtained were first translated into English by one student and then re-translated into Chinese by the other, without the two students ever interacting, in order to avoid any type of conditioning.

In addition, to make filling out the questionnaire easier and to avoid taking up too much of the respondents' time, it was decided to use only one of the two items suggested for each attribute by Echtner and Ritchie. Exceptions in this regard were made for the following attributes:

- "Tourist sites/activities", "National parks/wilderness activities", "Cities", "Hospitality/friendliness/receptiveness" and "Atmosphere (familiar vs. exotic)"; for each of these, two different items were developed in order to reduce the interpretative ambiguities that emerged during the exploratory study;

- "Historic sites/museums"; in consideration of the special nature of the artistic and cultural heritage of Italy, the following two items were used: "Numerous historical sites exist in Italy" and "Italy has not so many museums".

The formulation of the items was guided by the following criteria:

- Consistency with Chinese interpretative schemes. Where the respondents found the questions to be meaningless and/or irrelevant to the enquiry, the original formulation of the item was modified and adapted to their interpretative schemes so that they were set out more clearly. Particularly valuable in this regard was the feedback obtained during the pre-test of the questionnaire, as were the indications derived from Boo et al. (2009) and Papadoupolos et al. (2013).

- Speed of reading. In general terms, syntactic structures characterised by greater simplicity than the formulation of questions suggested by Echtner \& Ritchie (1991) were preferred. This led to the use of phrases such as "Italy has", rather than "Italy offers a lot in terms of", which was maintained only in one case, in order to diversify the formulation of the questions.

- Maintenance of the attention threshold of the respondents, above all in order to reduce the unwitting tendency to respond to all questions in the same way (Churchill, 1979). For this reason, every fifth item was given a negative formulation. During the processing of the answers however, these items were re-codified in a positive sense, in order to guarantee consistency in the measurement and a greater agility in the interpretation of the results.

The research was conducted on outbound Chinese tourists, defined as «non-agricultural, adult Mainland Chinese citizens who have taken a leisure trip of four or more nights, by plane, outside Asia in the past three years or plan to take one in the next two years» (Li, Harrill, Uysal, Burnett, \& Zhan, 2010, p. 253).

Due to the difficulty of identifying a probabilistic sample, widely discussed in the international literature with reference to research conducted on Chinese subjects (Roy, Walters, \& Luk, 2001), and considering the fact that Chinese citizens who are effectively able to afford a foreign holiday still constitute a very small proportion of the population and are not easily accessible (China Tourism Academy, 2010), it was decided to distribute the questionnaire on the basis of a convenient sample, seeking to identify groups that were as representative as possible of the population forming the subject of the investigation. Specifically, citizens resident in the three most populous municipalities in China (Beijing, Shanghai and Chongqing) were selected as these accounts for the largest numbers of outbound tourists, probably a consequence of their high average disposable income and rapid rate of development.

The questionnaire was distributed by email and was preceded by an explanatory text designed to illustrate the purposes of the research and gauge the effective willingness to participate in the questionnaire. Follow-up activities were also conducted via email.

All the responses obtained were translated into English, in order to facilitate statistical processing.

\section{Results}

Overall, 209 valid questionnaires were obtained in response to 300 emails sent. They contained assessments serving to identify — on the basis of the set of attributes developed from the model — the most significant factors that effectively determine Italy's image in the Chinese outbound leisure tourism market. They also contained a total of 7,397 images arising from the six open questions. In detail, the responses were distributed as follows: 711 images concerning the Functional/Holistic continuum, 503 images concerning the Psychological/Holistic continuum, 1,820 images concerning the Encouraging/Discouraging continuum, 718 images concerning the uniqueness component, 1,937 positive images and 1,708 negative images.

For the purposes of the investigation, the average and standard deviation was preliminarily calculated for each item. This served partly to assess, by means of statistical-descriptive analyses, the influence of the various 
attributes on the overall construct of the image and to provide, by such means, policy indications concerning the development of adequate promotion and commercialisation campaigns by the managers of Italian DMOs. The next step was to identify, by means of factorial analysis, the factors perceived as most representative of Italy (Gallarza et al., 2002). For the extraction of the factors, Principal Components Analysis was used.

In order to verify the presence of a significant correlation between the variables used, Bartlett's sphericity test, which tests the null hypothesis, i.e. absence of correlation between the variables, was performed, along with the Kaiser-Meyer-Olkin (KMO) test for sampling adequacy, which makes it possible to evaluate the partial correlations compared to the sum of observed correlations.

The results of the KMO index was 0.903 , and Bartlett's Test was significant, $p=0.000$, which met the minimum standard to proceed with the factor analysis. The EFA utilized principle axis factoring and Promax rotation with Kaiser normalization, and the criteria considered in the iterative process of the EFA included: retaining item coefficients greater than 0.4 , keeping only those factors with three or more items, and retaining factors with Eigenvalues greater than one (Gorsuch, 1997).

Next, a CFA was performed to assess the construct validity of the latent variables, and the initial model returned a good fit to the data, $(\chi 2(332)=649.868, \mathrm{p}<.0001, \mathrm{CFI}=.894, \mathrm{TLI}=.879, \mathrm{SRMR}=.062, \mathrm{RMSEA}=.068(90 \%$ CI .060 - .075).

The results are represented in Table 2.

Table 2. Factors defining Italy's destination image among Chinese travelers

\begin{tabular}{|c|c|c|c|c|c|c|c|c|c|}
\hline & & $\mathrm{F} 1$ & $\mathrm{~F} 2$ & F3 & $\mathrm{F} 4$ & F5 & F6 & F7 & F8 \\
\hline & & Welcome & $\begin{array}{l}\text { Cherish } \\
\text { of beauty }\end{array}$ & $\begin{array}{l}\text { Civiliza-t } \\
\text { ion }\end{array}$ & $\begin{array}{l}\text { Cautious } \\
\text { explora-t } \\
\text { ion }\end{array}$ & $\begin{array}{l}\text { China } \\
\text { every-where }\end{array}$ & Sport & $\begin{array}{l}\text { Fresh } \\
\text { enter-tai } \\
\text { n-ment }\end{array}$ & $\begin{array}{l}\text { Small } \\
\text { is } \\
\text { warm }\end{array}$ \\
\hline$\%$ Variance explained & & 32.45 & 7.67 & 5.87 & 4.29 & 3.27 & 3.05 & 2.73 & 2.49 \\
\hline Eigenvalue & & 14.6 & 3.45 & 2.64 & 1.93 & 1.47 & 1.37 & 1.23 & 1.12 \\
\hline Cronbach's alpha & & .867 & .839 & .858 & .878 & .783 & .787 & .685 & .667 \\
\hline \multicolumn{10}{|l|}{ Communalities } \\
\hline Personal safety & .717 & .741 & & & & & & & \\
\hline Prices & .716 & .677 & & & & & & & \\
\hline Service quality & .659 & .674 & & & & & & & \\
\hline Trust & .659 & .618 & & & & & & & \\
\hline Political stability & .665 & .614 & & & & & & & \\
\hline Adventure & .626 & .445 & & & & & & & \\
\hline Tourist activities & .598 & .427 & & & & & & & \\
\hline Tourist facilities & .600 & .394 & & & & & & & \\
\hline Scenery & .681 & & .725 & & & & & & \\
\hline $\begin{array}{l}\text { Historic sites and } \\
\text { museums }\end{array}$ & .637 & & .718 & & & & & & \\
\hline Churches & .663 & & .694 & & & & & & \\
\hline Architecture & .551 & & .667 & & & & & & \\
\hline Fine arts & .662 & & .585 & & & & & & \\
\hline Fashion and design & .645 & & .579 & & & & & & \\
\hline Reputation & .618 & & .486 & & & & & & \\
\hline Urbanization & .750 & & & .777 & & & & & \\
\hline $\begin{array}{l}\text { Extent of } \\
\text { commercialization }\end{array}$ & .736 & & & .666 & & & & & \\
\hline Cleanliness & .663 & & & .627 & & & & & \\
\hline Local transportation & .713 & & & .591 & & & & & \\
\hline $\begin{array}{l}\text { Economic } \\
\text { development }\end{array}$ & .628 & & & .579 & & & & & \\
\hline Shopping facilities & .598 & & & .566 & & & & & \\
\hline Rest and relax & .708 & & & & .693 & & & & \\
\hline Opportunity to learn & .701 & & & & 669 & & & & \\
\hline Customs/culture & .653 & & & & 610 & & & & \\
\hline Exotism & .745 & & & & .590 & & & & \\
\hline Family oriented & .659 & & & & .568 & & & & \\
\hline Lifestyle & .745 & & & & .547 & & & & \\
\hline
\end{tabular}




\begin{tabular}{|c|c|c|c|c|c|c|}
\hline Food & .657 & .498 & & & & \\
\hline Accessibility & .729 & .495 & & & & \\
\hline Crowdedness & .609 & & .695 & & & \\
\hline Atmosphere (familiar) & .697 & & .678 & & & \\
\hline Movies & .616 & & .568 & & & \\
\hline Fishing/hunting & .754 & & .530 & & & \\
\hline $\begin{array}{ll}\text { Ease } & \text { of } \\
\text { communication }\end{array}$ & .665 & & .484 & & & \\
\hline Cities & .658 & & .466 & & & \\
\hline Sport facilities & .775 & & & .770 & & \\
\hline Soccer & .747 & & & .753 & & \\
\hline Nightlife & .663 & & & & .751 & \\
\hline Fairs and festivals & .604 & & & & .582 & \\
\hline National parks & .543 & & & & .413 & \\
\hline Towns & .777 & & & & & .796 \\
\hline Beaches & .618 & & & & & .480 \\
\hline Climate & .543 & & & & & .416 \\
\hline
\end{tabular}

Note. Kaiser-Meyer-Olkin measure of sampling (KMO): .903. Bartlett’s test of sphericity: 5343.264. Significance: .000.

In a subsequent phase of the investigation, the factors identified by factor analysis were then considered as new macro-variables, to which cluster analysis was applied using the non-hierarchical K-means method, in order to segment the outbound Chinese tourism market (Table 3).

Table 3. Cluster Analysis

\begin{tabular}{|c|c|c|c|c|c|c|c|}
\hline \multirow[t]{2}{*}{ Factors } & \multicolumn{4}{|l|}{ Segments } & \multicolumn{3}{|c|}{ Anova } \\
\hline & $\begin{array}{l}\text { Cluster 1 } \\
\text { Vase } \\
\text { Connoisseurs } \\
(\mathrm{n}=27)\end{array}$ & $\begin{array}{l}\text { Cluster } 2 \\
\text { Freshwater } \\
\text { crocodiles } \\
(\mathrm{n}=52) \\
\end{array}$ & $\begin{array}{l}\text { Cluster } 3 \\
\text { Long-tailed } \\
\text { kites } \\
(\mathrm{n}=26)\end{array}$ & $\begin{array}{l}\text { Cluster } 4 \\
\text { Snowflakes } \\
\text { on bamboo } \\
(\mathrm{n}=28) \\
\end{array}$ & $\begin{array}{l}\text { Cluster } 5 \\
\text { Dry-foot } \\
\text { fishermen } \\
(\mathrm{n}=75)\end{array}$ & $\mathrm{F}$ & Sig. \\
\hline Welcome & -.62706 & -.13100 & -.93593 & .09396 & .60595 & 21.735 & .000 \\
\hline $\begin{array}{l}\text { Cherish of } \\
\text { beauty }\end{array}$ & .45478 & .41734 & .21493 & -1.72441 & .11620 & 47.536 & .000 \\
\hline Civilization & .00666 & -.87506 & .37653 & -.39505 & .62127 & 29.950 & .000 \\
\hline $\begin{array}{l}\text { Cautious } \\
\text { exploration }\end{array}$ & -.55505 & -.58894 & 1.00414 & -.06281 & .28350 & 20.092 & .000 \\
\hline $\begin{array}{l}\text { China } \\
\text { everywhere }\end{array}$ & .46255 & -.20315 & -.80819 & -.14861 & .30999 & 9.532 & .000 \\
\hline Sport & .45187 & -.12573 & -.76351 & -.44527 & .35542 & 10.871 & .000 \\
\hline $\begin{array}{l}\text { Fresh } \\
\text { entertain-ment }\end{array}$ & -1.40847 & .59433 & -.23031 & -.28258 & .28032 & 32.916 & .000 \\
\hline Small is warm & -.26743 & .38603 & .19682 & -.58827 & -.01998 & 5.550 & .000 \\
\hline
\end{tabular}

For the analysis of the data emerging from the open questions, content analysis tools were used (Weber, 1990; Neuendorf, 2001), in order to identify and categorise specific words and phrases (especially common and proper nouns) used by the respondents. With reference to the tourism sector, the international literature considers nouns in particular as mainly indicative of destination-specific resources, verbs as descriptors of the various types of tourism goods and services on offer, and adverbs and adjectives as elements that describe the holiday in terms of its experiential dimension (Echtner, 2002).

Before starting this analysis, the first step was the normalisation and codification of the data (Miles \& Huberman, 1994). This made it possible to reduce the number of images associated with the Functional/Holistic continuum to 93, with the Psychological/Holistic continuum to 40 and with the Encouraging/Discouraging continuum to 53, in addition to 56 images associated with the uniqueness component, 112 images with a positive association and 92 images with a negative association.

From the preliminary analysis of the data, two significant tendencies emerged: the first is that the respondents often cite composite images (i.e., images in which a number of items appear together, as in the case of «harmonious human environment» and «rich cultural atmosphere»). The second is that the same image is 
sometimes cited by respondents with reference to different continua. Consider for example the case of «Rome», mentioned in the answer to the question "What images or characteristics come to mind when you think of Italy as a vacation destination?" as well as in the answer to the question "Please list any distinctive or unique tourist attractions that you can think of in Italy".

Both these tendencies seem to call for the application, as has become frequent in the tourism sector in the last few years (Li \& Stepchenkova, 2011; Zenker \& Beckmann, 2013), of the brand associative network model (Cai, 2002; Keller, 1993), according to which the brand can be considered a «network of associations in the consumer's mind based on the visual, verbal, and behavioral expression of a place, which is embodied through the aims, communication, values, and the general culture of the place's stakeholders and the overall place design» (Zenker \& Braun, 2010, p. 3). Adopting this interpretative framework, and consistent with Anderson's theory of Adaptive Control of Thought (1983), activities in support of destination identity are based on the assumption that «these associations can be manipulated to create a better brand for a place» (Sevin, 2014, p. 48). Furthermore, the study and measurement of a tourism destination image consist of «identifying the most relevant associations and strengthening their linkages to the brand» (Cai, 2002, p. 723), accomplished by means of associative and semantic maps as the preferred tools of enquiry.

To this end, in the present study, cases of co-occurrence of two or more images were identified and analysed by calculating the Z score (Li \& Stepchenkova, 2011), in order to reconstruct the most significant associations between one item and another in the minds of the respondents while excluding all cases of mere coincidence.

For the study of the frequencies and the semantic analysis of the information gleaned from the answers to the open questions, CATPAC software (Woelfel, 1993; Jani \& Hwang, 2011; Pan et al., 2007) was used. The data from the closed-response questions were processed using SPSS software.

\section{Discussion and Managerial Implications}

The outbound Chinese tourist is of low average age (25 to 44 years) and a high level of education (more than $70 \%$ have a high-school diploma and/or a degree).

Although the concept of "flexibility" is not culturally alien to them, they prefer to set off only after having conducted a rigorous process of selection, focused above all on which tourism operators to trust and the people they intend to travel with (mainly chosen from friends, family members and colleagues). In the choice of destination, close attention is also paid to factors such as hygiene and personal safety. In more general terms, it can be said that for the Chinese tourist it is very important to read up on the places that they will visit before setting off. Traditionally, tour operators, newspapers and magazines are the main sources of information, but the importance of word-of-mouth communication among family and friends is growing continuously, as is the role of social networks. Aside from these shared characteristics, it is however possible to formulate a hypothetical segmentation of the Chinese outbound tourism market on the basis of the analysis of the main attractiveness factors associated with Italy (see Table 3).

\subsection{Dry-foot Fishermen}

The tourist belonging to this segment adopts a more traditional approach to travel. Specifically, these tend to be people born in the 1950s and 60s who travel in a group and only purchase organised packages from tour operators, staying in at least four or five different countries. Even if it is their first journey abroad and their knowledge of English is limited, these are not ill-prepared tourists: they already have a clear idea of the sites that they will visit and what they will buy. The process by which they make their choices is guided by two fundamental considerations: the cost of the package and the reputation of the travel agency they buy from.

The typical profile is that of a tourist who arrives in Italy after having been in France and Germany (because Paris and Frankfurt have the most direct flight connections with China) and stays in the country only for a few days, often spending every night in a different city. Usually the itinerary includes Milan (where they spend about $40 \%$ of their total budget), Venice (with a bet at the casino), Florence (particularly attractive due to the proximity of museums and shopping outlets) and Rome, where they board planes to return to China. The "Dry-foot fishermen" is only interested in visiting the most famous places and buying souvenirs; he/she is very firm about maintaining their traditions while abroad (for example eating only in Chinese restaurants at typically Chinese times, and following particular rituals linked to numbers). For this reason, they strongly appreciate it when, during a visit, the guide (who must have excellent knowledge of western art), highlights links between the places they are visiting and typical elements or details of Chinese history and culture.

\subsection{Vase Connoisseurs}

These are "return tourists": economically well-off, often they have already been to Italy for work or study and 
were so impressed that they decided to return on holiday for a more detailed visit. Lovers of shopping and Made in Italy brands, they expect a high level of service and comfort. For this reason, for the organisation of their holiday they turn to travel agencies and tour operators.

For these tourists, travelling is also a way of exerting China's "soft power" in the destination country. For this reason, they consider a service to be of "quality" only if it satisfies three fundamental criteria: firstly, functionality (the service is provided in a punctual and timely fashion, the staff are well trained, etc.); secondly the degree of consideration for the guests (which Italian operators can show for example by using flags and having material prepared in Chinese); lastly, respect for the principle of mianzi (which involves addressing or serving the oldest or highest-ranking in a group first, not interrupting or explicitly criticising, and not expressing a categorical refusal in public). (Note 1)

The "Vase connoisseurs" like packages with lots of activities, but also free time, which they tend to spend on open-air sports such as golf or cycling. They visit fewer countries (usually two or three) than the "Dry-foot fishermen", because they prefer more in-depth visits which allow them greater contact (albeit highly mediated) with the culture of the place they are visiting. For them travel has a strong symbolic component. For this reason, in the choice of destination they pay great attention to the value for money aspect (the price of the package with respect to what it includes). In addition, on their return, they like to consolidate their prestige in the community of reference by telling relative friends and acquaintances about their experiences.

\subsection{Long-tailed Kites}

This rapidly growing segment is composed of FITs ("Free and Independent Travellers") who travel on average two or three times a year, preferring mono-destination journeys with thematic itineraries. They fly in first class, stay in 5-star hotels belonging to large international chains and often bring their domestic staff with them. These tourists (both men and women) are well-educated, with an average age of 38 and high disposable income. They are often single or couples without children. Lovers of "made-to-measure" holidays that favour relaxation and well-being, they demand high standards of quality (for them, "quality" being synonymous with "luxury") and highly personalised service. When they travel, they expect to be able to experience - in a highly immersive way - the lifestyle of the country they are staying in. For this reason, they do not disdain less-famous destinations, as long as they are characterised by "excellence".

\subsection{Snowflakes on Bamboo}

Tourists falling within this cluster have an average age of less than 40, a high level of education and an income slightly lower than that of the "Long-tailed kites". They show negative averages for nearly all of the macro-variables on which this analysis was developed. The only element that can identify this segment is hospitality, intended here as well, as the emphasis on the service component.

So, on a par with the "Dry-foot fishermen", Italy's image is defined exclusively by the functional component: however, unlike them, the "Snowflakes on Bamboo" have virtually no interest in the fame and beauty of the places they visit, or for the variety and exclusiveness of the tourist offer, which, on the other side, are remarkable elements of choice for the "Vase connoisseurs" and the "Long-tailed kites", respectively.

\subsection{Freshwater Crocodiles}

China's "Generation Y" tourists are oriented towards success and are less bound to traditional culture than their parents. They view western values with curiosity and interest, travelling alone and/or with friends in a sort of "grand tour" across Europe, oriented towards shopping and fun. In order to keep together, they prefer not to stay in hotels but to rent villas or stay as guests in the houses of acquaintances. The essential thing for them is have access to fast wi-fi, so they can find out in advance about the places that they are to visit and above all share their travel experiences online in real time. Since they are students or professionals who have started work only recently, their disposable income is not high, but they are prepared to spend large sums in order to enjoy experiences that are consistent with their interests. For example, they very much like tasting local foods and meeting local people, as well as visiting less well-known locations.

As digital natives, they are inevitably drawn to re-interpret one of the founding values of Chinese social fabric - i.e., guanxi - from a Web 2.0 perspective (Note 2). Thus, even in their choice of holiday destination they do not seek advice from travel agencies, but are guided by word-of-mouth tips and the dominant opinions among their peer group, expressed almost exclusively via social networks or, more generally, the Internet, which for them is the key space for obtaining information.

The sum of favourable or unfavourable judgements, opinions, sentiments and impressions of people who have been or are about to go on holiday is one of the fields on which, today, competition between international 
destinations is played out, because the control of the flow of information is less and less in the hands of management and more and more in the hands of the tourist. However, it is also because for Chinese tourists, the quality of accommodation, the beauty of the landscape and the hospitality of the people are increasingly seen as points of parity, i.e., elements that are necessary but not sufficient to act as specific attractors in the choice of a potential visitor.

Considering the Attributes and Holistic components, of both a functional and psychological nature (Fig. 5), it emerges that Chinese tourists, with no significant distinction into segments, consider Italy to be the home of style. Revealing in this context is the wealth of references to "fashion", "high-quality handicraft") and fine living.

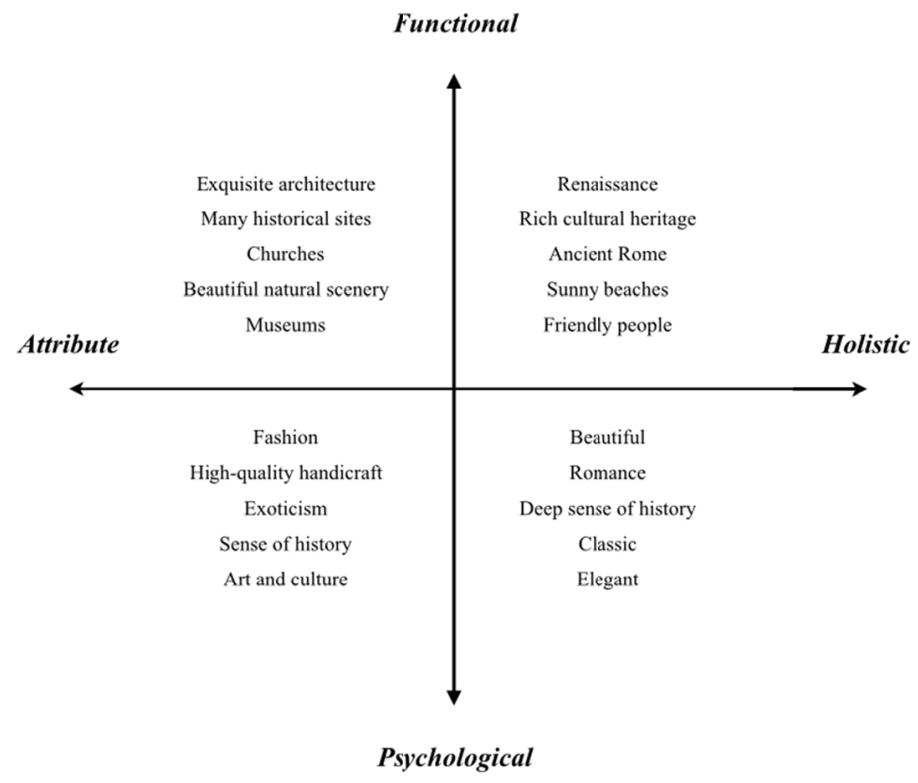

Figure 5. Elements characterising the image of Italy along the Attributes vs. Holistic and Functional vs. Psychological axes

Long-haul travellers in particular appreciate Italy's historic and artistic heritage, which offers "a lot to see" and "a lot to do", but there are also complaints about the "high costs" often associated with these activities (especially from the "Dry-foot fishermen" and the "Freshwater crocodiles"). In this regard, consider the references to "museums" and "churches": the latter in particular hold a special charm for Chinese tourists, not only due to the artistic heritage they contain but also because, as most of them are atheists, they are curious about sacred rituals, wishing to know more, if not in detail. Similarly, they are strongly interested in any connections between the religious orders associated with the building being visited and figures such as Matteo Ricci and Martino Martini, well-known and liked in China. Interest in architectural heritage, though very high in general terms, depends on the type of tourist. Indeed, while the "Dry-foot fishermen" especially like modern architecture, the "Vase Connoisseurs" and "Long-tailed kites" seek the right balance between antiquity and modernity, being particularly attracted by the pomp of the Roman Empire (the Chinese consider the Italians to be the direct descendants of the Romans and compare the events of ancient Rome with their own ancient civilisation) and the cultural production of the Renaissance.

Italy is not seen as the only country in Europe with rich historic, artistic and cultural heritage. However, it is only in Italy, according to Chinese tourists, that one can sense a certain happy and easygoing atmosphere, a sort of magic, rich in evocations. This atmosphere seems more intense in cities such as Rome and Venice (due to their being known for both art and shopping, appreciated by the "Dry-foot fishermen" segment, while their extensive historic, artistic and cultural heritage is appreciated by middle-to-upper class tourists). However, it is also sought (above all by those who desire to combine luxury, well-being, culture and food-and-wine) in localities such as Naples, Turin and Verona. Indeed, there is a strong connection between the latter city and opera, which is one of the images most frequently matched with Italy by Chinese tourists, together with design/fashion, gastronomy (in terms of pasta and pizza and, to a lesser extent, wine) and art. Other areas of interest include Lake Como and Sicily. The city of Milan is recognised and admired as the "capital of fashion", although a growing percentage of 
tourists are also able to cite, with no visual prompting, monuments such as the Cathedral and the Sforza Castle, as well as remembering, more predictably, the big Made in Italy brands.

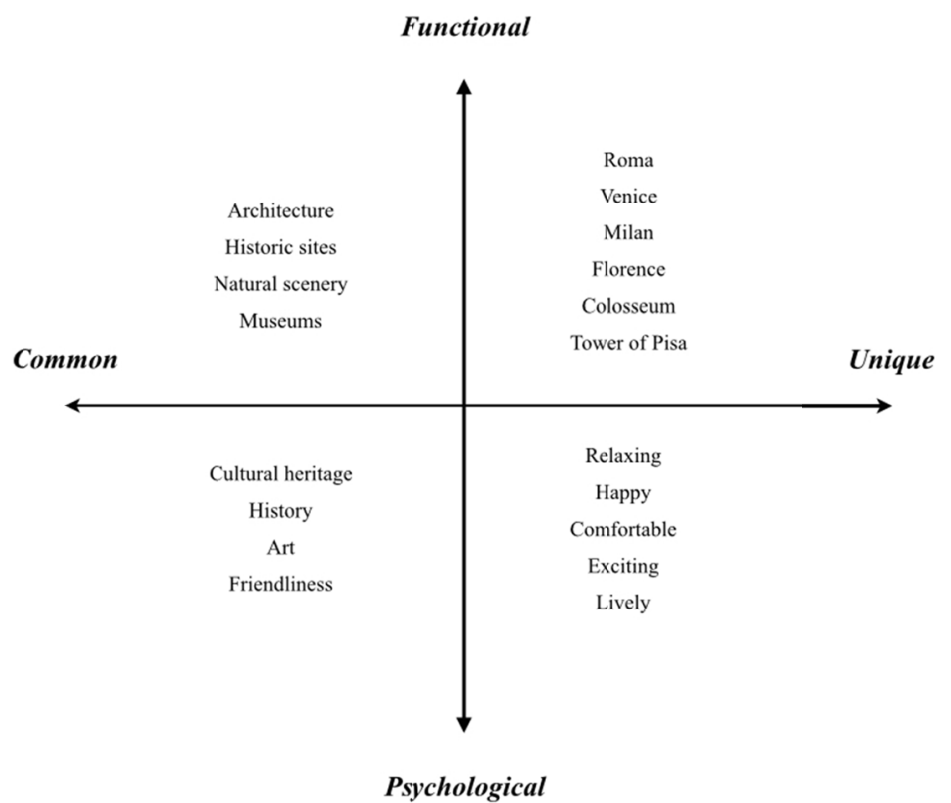

Figure 6. Elements characterising the image of Italy along the Functional vs. Psychological and Common vs.

Unique axes

Despite being more interested in cities (which they often associate with football teams), a segment is developing in the variegated Chinese tourism market that is quantitatively limited but is growing at a promising rate: nature tourism. From this point of view however, it should be pointed out that with reference to Italy the "natural landscape" still lies within the "functional/common" quadrant (Figure 6) and thus does not represent a factor of attractiveness that can differentiate the country from its competitors. In addition, Chinese tourists' knowledge of Italian natural heritage is still superficial and generic, as shown by their inability to name anything more than the "Alps" and the "Mediterranean Sea", which, however, is sometimes confused with the Aegean Sea.

In China, Italy enjoys a good reputation, accompanied by a strong aspirational and status component. In this case too however, we are dealing not so much with elements of differentiation as with small details characterising the range of tourism goods and services on offer (consider the "Holistic/Common" quadrant in Figure 7).

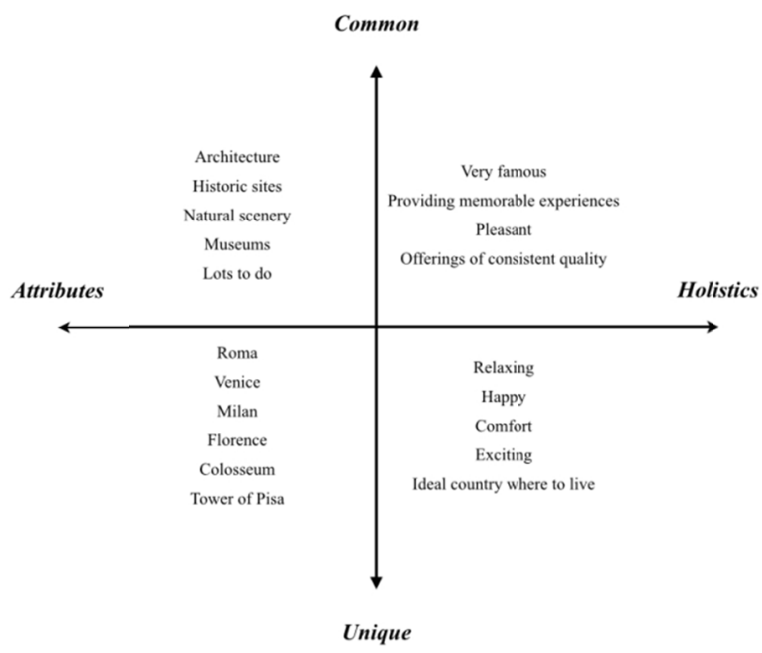

Figure 7. Elements characterising the image of Italy along the Attributes vs. Holistic and Common vs. Unique axes 
The truly unique feature that Chinese tourists expects to find in Italy, especially if they belong to the "Long-tailed kites" and "Freshwater crocodiles" segments, is linked to the experiential component, which translates into the desire to "discover local habits" or, in more general terms, to gain a less superficial knowledge of the places visited and to fully experience the region, enjoying its culture and traditions. For this reason, the readiness of guides to enrich the description of landscapes and monuments with the history, culture, gastronomy, cinema, literature and famous personages linked to the places is highly appreciated by the "Long-tailed kites". Packages which combine accommodation services with guided visits to the region's best assets, especially in the handicraft, food-and-wine and fashion sectors, are also very popular.

From these considerations, it emerges that aside from the stereotypes linked to "fashion", "football" and "romanticism/passion" (also understood as "the possibility of having a love affair"), in the minds of outbound Chinese tourists the image of Italy is gradually being enriched with details. Many of these (linked above all to the concepts of "beauty", "style", "elegance" and a "sense of history") act as inducements to purchase a holiday in Italy. However, there is no lack of other images which in contrast cast a bad light on Italy as a tourist destination (the most frequently mentioned are associated with "poor safety/security"-including health concerns- "chaos", "litter", "theft" and natural phenomena such as "earthquakes"), prompting Chinese tourists to choose other destinations from Italy's competitors (Fig. 8).

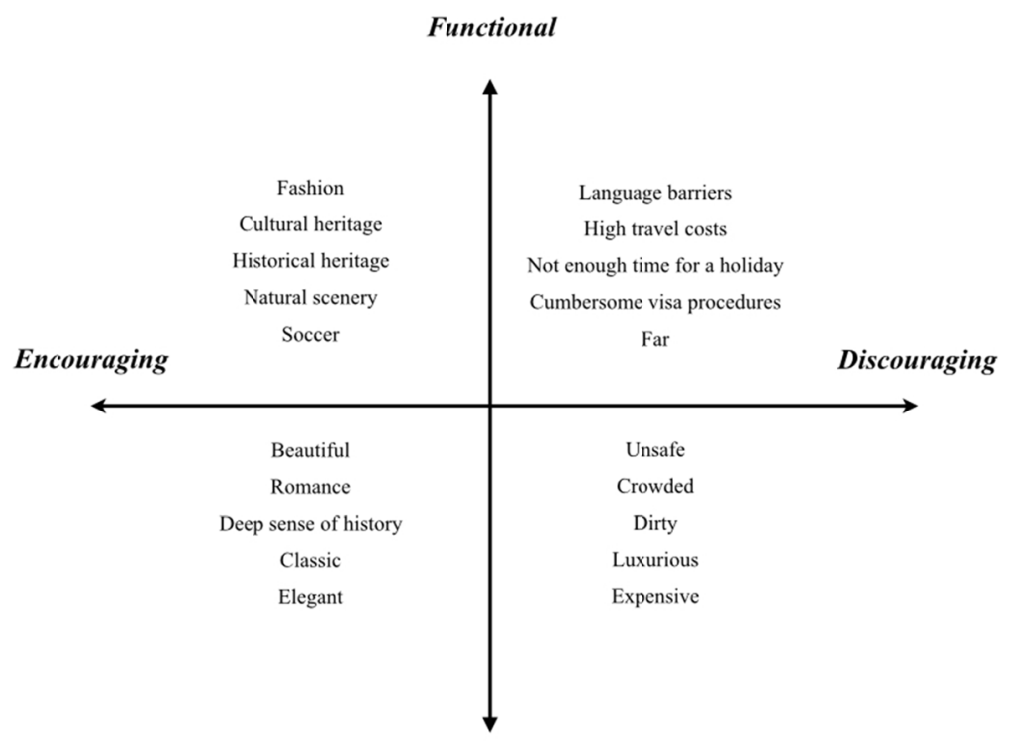

Psychological

Figure 8. Functional and psychological attributes that act as encouraging and discouraging factors for a holiday in Italy

These elements may be added to those traditionally mentioned by travellers from the People's Republic of China as factors discouraging them from visiting Italy, especially concerning its poor geographical accessibility (the lack of direct flights, infrastructure problems that make it difficult to reach locations south of Rome and the disruption caused by frequent strikes) and lack of information (especially the absence of signs and menus written in Chinese script), both before and during the holiday. Other problems include the difficulty and delays involved in getting a visa; the language barrier, sometimes perceived as a symptom of poor professionalism on the part of tourism operators; and the high costs of staying in Italy.

From what has been set out so far, it emerges that in order to be attractive to the various segments that make up this market, Italy must construct its image by carefully mixing functional, symbolic and experiential elements. Specifically, tourism operators need to concentrate their efforts on two levels of intervention, on the one hand implementing measures of a general nature designed to enhance the sense of "ease", "hospitality" and "comfort" that Chinese tourists feel when they arrive in Italy, and on the other, adopting a logic for the promotion and construction of products and services that is consistent with the specific features and needs of the various target 
segments identified.

On a general level, it is necessary to increase the production of information materials in Chinese, and to adopt a multi-channel approach that encompasses books and magazines but does not neglect web platforms such as Weibo, RenRen and Qzone.

Moreover, the development of better coordinated and less episodic measures, the consolidation of the relational network with autochthonous partners (following the logic of guanxi) and the reinforcement of specific skills among the operators would make it possible to develop new tourism products, diversified and personalised, created in accordance with criteria that depend on the segment being served.

Whereas for example broadening the range of goods and services on offer may represent an effective strategy for winning over the "Dry-foot fishermen", deepening it would be so for the "Vase connoisseurs", just as an emphasis on authenticity is required for the "Long-tailed kites" and virality for the "Freshwater crocodiles".

Given that for the "Dry-foot fishermen" the goal of travelling is to maximise the number of localities visited in quantitative terms, tour operators seeking to cater to this segment need to play a more active role in the promotion campaigns (on and offline) of the destination country, to intensify cooperation with Chinese tourism companies and to vertically integrate the production chain.

In contrast, for the "Vase connoisseurs"and the "Snowflakes on bamboo" it is important to feel that they are being treated with consideration. For this reason, it may be advisable to hire Chinese staff and to set up more "Chinese friendly" environments. In this regard, hoteliers (Note 3) need to equip their rooms with kettles, teabags (green tea), laundry drying racks in the bathroom and Chinese satellite television channels, as well as enriching their menus with basic Chinese dishes such as rice soup, soya noodles and fried doughnuts. In addition, they could make Chinese newspapers available in the lobby and provide, as already suggested, packages in which their stay is associated with shopping tours and guided visits to city's monuments. Lastly, considering their eagerness (shared with the "Dry-foot fishermen") to tell others about their trip, it may also be useful to create a sort of "seal" or "stamp" of quality that certifies their visit, perhaps to be issued as they leave a museum.

For tourists of the "Long-tailed kites" segment, the advice is to adopt the thematic itinerary approach, choosing a characterising theme around which to build a proposal for a diverse range of experiences. Also essential is attention to detail (for example, welcoming them with a sincere smile and warm greeting in their language) and a readiness to resolve any problems that may arise. Chinese tourists do not appreciate vague answers such as "I don't know" or, even worse, "that's not our problem". On the contrary, they expect to obtain information of a practical nature that will help them to choose, concerning both gastronomy (where they appreciate clear presentation of local foods, wines and spirits), and opportunities to engage with different cultures. For this reason, for example, they look for Chinese audio guides or QR codes that link to explanatory web pages written in Chinese. In addition, they are very interested in brochures that present events and shows, especially when associated with the local folklore.

Lastly, when concentrating one's marketing efforts on the "Freshwater crocodiles" segment, the flexibility component, and above all a pervasive online presence, are strategically important: given the role played by word-of-mouth for this type of tourist-before, during and after the holiday-tourism operators are advised to carefully monitor their online web reputation, by means of a systematic analysis of opinions posted by users on generalist and thematic social networks.

\section{Conclusions}

This study sought to measure the image of Italy as a tourism destination on the Chinese leisure traveller market. To this end, the Echtner \& Ritchie's model (1991) was applied, considering its ability to provide an exhaustive and intuitive representation of the various components that combine to create the destination image. However, compared to its original formulation, it was implemented with greater consideration of the experiential dimension in the consumption of the tourist product, in particular via the provision of a series of multisensory stimuli that can generate feelings and/or thoughts in the visitors, then suggesting the opportunity to consider Tourism Destination Image (TDI) in a hedonistic perspective.

In these terms, the study expands existing Tourism Destination Image (TDI) measurement research by making the following contributions to literature, and to management practice.

First of all, it increases our understanding of how TDI can be defined and measured. In fact, it proposes not just a denotative, but also and above all a connotative measurement of the image, thereby reducing the risk of ambiguity in the interpretation of the most significant attributes that emerged during the analysis. 
In detail, a different view of Tourism Destination Image is suggested by exploring the role of the elements that, on the one side, are attractive to the specific segment of interest and, on the other side, potentially undermine the image of a destination in the perception of the range of tourism goods and services on offer. To this end, a fourth continuum named Encouraging vs. Discouraging is integrated into Echtner and Ritchie's model with which to perform the measurement of the image.

Using this approach, the image Chinese outbound leisure tourists held about Italy has been measured, then filling a gap in managerial literature where, to the Authors' knowledge, existing studies do not target the Asian market, but rather analyze Italy in terms of a wider Mediterranean destination, only partially identifying country-specific strategies for strengthening tourism flows within the country.

Moreover, by adopting a hypothetical segmentation of the market in question, a foundation for Italian destination managers to adopt Chinese tailor-made approaches to the construction and promotion/commercialisation of tourism products and design effective marketing strategies is built, which represents an opportunity for the country to gain competitive advantage in a market which is undergoing rapid diversification.

In fact, the results of the qualitative and quantitative investigations demonstrated that overall, outbound Chinese tourists consider Italy to be a destination for holidays centred on relaxation, comfort and art-and-culture. However, they also voice growing concerns about certain aspects of staying in the country, such as the chaos and poor organisation or, with specific reference to tourism goods and services, a system that is poorly adapted to their needs and expectations.

The risk is that of an increasingly sharp discrepancy between the secondary and primary images of Italy, due to a failure to fulfil the potential of its enormous historic, cultural and natural heritage. In this sense, a consolidation of the national tourism sector's system of governance and the application of policies designed to strengthen the destination's resources may enable the creation of a series of highly flexible and personalised products and experiences, which would also have clear benefits in terms of the de-seasonalisation of flows.

For the framework set out above to be considered truly exhaustive however, it is necessary to conduct an investigation to measure Italy's image among the various players who help to shape it and disseminate it. We refer here in particular to the mass media, social networks and numerous participants in the tourism production chain, whose role as "image shapers" is widely recognised by the international literature (Llodrà-Riera et al., 2015). A further issue arises from the choice of sample, which does not allow for full generalisation of the results. Nor should we overlook the tendency of Chinese respondents to provide answers which they believe will satisfy the researchers' expectations (Adler, Campbell, \& Laurent, 1989). Lastly, in a study of destination image, the possibility that the answers provided are affected by the state of diplomatic relations, the period when the questionnaires were filled in, the long distance between Italy and China, and other environmental factors, cannot be ruled out (Reilly, 1990).

Presenting a tourism destination means integrating its identity with all of its multiple images and making the most of the network of reciprocal influences that they activate. It would be advisable therefore to adopt a more dynamic approach to the task of measurement, for example by developing indices that are sensitive enough to assess whether and how, over the course of time, the image that a group of consumers has of Italy as a tourism destination reflects changes in the socio-political, economic and cultural context of the specific market being studied. In addition, this may provide indications on how to optimise Italy's positioning with respect to its main international competitors, in the awareness that destination image and country image are constructs with broad areas of overlap and reciprocal interdependence.

Lastly, China represents only one of the tourism markets to watch with interest. It would therefore be advisable to extend the investigation to other large markets, including Russia, India and Brazil, analysing any differences between the various national groups in terms of their perception of the attributes that characterise Italy as a tourism destination.

\section{References}

Aaker, D., \& Joachimsthäier, E. (1999). The Lure of Global Branding. Harvard Business Review, 77(6), 137-144.

Adler, N. J., Campbell, N., \& Laurent, A. (1989). In search of appropriate methodology: From outside the People's Republic of China looking in. Journal of International Business Studies, 61-74. https://doi.org/10.1057/palgrave.jibs.8490351

Agapito, D., Mendes, J., \& Valle, P. (2013). Conceptualizing the sensory dimension of tourist experiences. Journal of Destination Marketing \& Management, 2(2), 62-73. https://doi.org/10.1016/j.jdmm.2013.03.001 
Ambasciate/Consolati/ENIT. (2015). Cina $e$ Hong Kong. Retriverd from http://www.esteri.it/mae/pdf_paesi/asia/cina.pdf

Anand, P., Holbrook, M. B., \& Stephens, D. (1988). The formation of affective judgments: The cognitive-affective model versus the independence hypothesis. Journal of Consumer Research, 15(Dec.), 386-391. https://doi.org/10.1086/209176

Anderson, J. (1983). The Architecture of Cognition. Cambridge, MA: Harvard University Press.

Andreu, R., Claver, E., \& Quer, D. (2014). Destination Attributes and Chinese Outbound Tourism to Europe. Journal of China Tourism Research, 10(3), 275-291. https://doi.org/10.1080/19388160.2013.855692

Anholt, S. (2007). What is Competitive Identity?. Competitive Identity (pp. 1-23). London, UK: Palgrave Macmillan. https://doi.org/10.1057/9780230627727_1

Baloglu, S. (2001). Image variations of Turkey by familiarity index: informational and experiential dimensions. Tourism Management, 22(2), 127-133. https://doi.org/10.1016/S0261-5177(00)00049-2

Baloglu, S., \& Mangaloglu, M. (2001). Tourism destination images of Turkey, Egypt, Greece, and Italy as perceived by US-based tour operators and travel agents. Tourism Management, 22(1), 1-9. https://doi.org/10.1016/S0261-5177(00)00030-3

Baloglu, S., \& McCleary, K. W. (1999). A model of destination image formation. Annals of Tourism Research, 26(4), 868-897. https://doi.org/10.1016/S0160-7383(99)00030-4

Baloglu, S., \& McCleary, K. W. (1999). US international pleasure travelers' images of four Mediterranean destinations: A comparison of visitors and nonvisitors. Journal of Travel Research, 38(2), 144-152. https://doi.org/10.1177/004728759903800207

Barich, H., \& Kotler, P. (1990). A framework for marketing image management. Sloan Management Review, 32(2), 94-104.

Beerli, A., \& Martin, J. D. (2004). Factors influencing destination image. Annals of Tourism Research, 31(3), 657-681. https://doi.org/10.1016/j.annals.2004.01.010

Behling, O., \& Law, K. S. (Eds.) (2000). Translating Questionnaires and Other Research Instruments: Problems and Solutions (Quantitative Applications in the Social Sciences). Thousand Oaks, CA: Sage. https://doi.org/10.4135/9781412986373

Bigné, J. E., Sanchez, M. I., \& Sanchez, J. (2001). Tourism image, evaluation variables and after purchase behaviour: inter-relationship. Tourism Management, 22(6), 607-616. https://doi.org/10.1016/S0261-5177(01)00035-8

Bitner, M. J. (1992). Servicescapes: The impact of physical surroundings on customers and employees. The Journal of Marketing, 57-71. https://doi.org/10.4135/9781412986373

Blain, C., Levy, S. E., \& Ritchie, J. B. (2005). Destination branding: Insights and practices from destination management organizations. Journal of Travel Research, 43(4), 328-338. https://doi.org/10.1177/0047287505274646

Boo, S., Busser, J., \& Baloglu, S. (2009). A model of customer-based brand equity and its application to multiple destinations. Tourism Management, 30(2), 219-231. https://doi.org/10.1016/j.tourman.2008.06.003

Buhalis, D. (2000). Marketing the competitive destination of the future. Tourism Management, 21(1), 97-116. https://doi.org/10.1016/S0261-5177(99)00095-3

Burnett, J. J., \& Baker, H. B. (2001). Assessing the travel-related behaviors of the mobility-disabled consumer. Journal of Travel Research, 40(1), 4-11. https://doi.org/10.1177/004728750104000102

Cai, L. A. (2002). Cooperative branding for rural destinations. Annals of Tourism Research, 29(3), 720-742. https://doi.org/10.1016/S0160-7383(01)00080-9

Campos, A. C., Mendes, J., Oom do Valle, P., \& Scott, N. (2015). Co-creation of tourist experiences: a literature review. Current Issues in Tourism, 1-32. https://doi.org/10.1177/004728750104000102

Carbone, L. P., \& Haeckel, S. H. (1994). Engineering customer experiences. Marketing Management, 3(3), 8-19.

Carneiro, M. J., \& Crompton, J. L. (2010). The influence of involvement, familiarity, and constraints on the search for information about destination. Journal of Travel Research, 49(4), 451-470. https://doi.org/10.1177/0047287509346798 
Cesif-Centro Studi per le imprese Fondazione Italia Cina. (2014). Rapporto Annuale "La Cina nel 2014". Milan.

Chen, H. J., Chen, P. J., \& Okumus, F. (2013). The relationship between travel constraints and destination image: A case study of Brunei. Tourism Management, 35, 198-208. https://doi.org/10.1016/j.tourman.2012.07.004

Chen, N., Ji, S., \& Funk, D. C. (2014). An extended study on destination image decay of sport tourists over time. Journal of Destination Marketing \& Management, 2(4), 241-252. https://doi.org/10.1016/j.jdmm.2013.11.001

Chen, P. J., Hua, N., \& Wang, Y. (2013). Mediating perceived travel constraints: The role of destination image. Journal of Travel \& Tourism Marketing, 30(3), 201-221. http://dx.doi.org/10.1080/10548408.2013.774914

Chew, E. Y. T., \& Jahari, S. A. (2014). Destination image as a mediator between perceived risks and revisit intention: A case of post-disaster Japan. Tourism Management, 40, 382-393. https://doi.org/10.1016/j.tourman.2013.07.008

Chick, G., \& Dong, E. (2005). Cultural constraints on leisure. In E. L. Jackson (Ed.), Constraints to Leisure (pp. 169-183). State College, Pennsylvania: Venture Publishing.

China Tourism Academy. (2010). Annual report of China outbound tourism development 2009/2010. Munchen: Profil.

Churchill Jr, G. A. (1979). A paradigm for developing better measures of marketing constructs. Journal of Marketing Research, 64-73. https://doi.org/10.2307/3150876

Crawford, D. W., \& Godbey, G. (1987). Reconceptualizing barriers to family leisure. Leisure Sciences, 9(2), 119-127. https://doi.org/10.1080/01490408709512151

Crawford, D. W., Jackson, E. L., \& Godbey, G. (1991). A hierarchical model of leisure constraints. Leisure Sciences, 13(4), 309-320. https://doi.org/10.1080/01490409109513147

Crouch, G. I. (2011). Destination competitiveness: an analysis of determinant attributes. Journal of Travel Research, 50(1), 27-45. https://doi.org/10.1177/0047287510362776

Dadgostar, B., \& Isotalo, R. M. (1996). Content of city destination image for near-home tourists. Journal of Hospitality \& Leisure Marketing, 3(2), 25-34. http://dx.doi.org/10.1300/J150v03n02_03

Daniels, M. J., Rodgers, E. B. D., \& Wiggins, B. P. (2005). "Travel Tales": an interpretive analysis of constraints and negotiations to pleasure travel as experienced by persons with physical disabilities. Tourism Management, 26(6), 919-930. https://doi.org/10.1016/j.tourman.2004.06.010

Datzira-Masip, J., \& Poluzzi, A. (2014). Brand architecture management: The case of four tourist destinations in Catalonia. Journal of Destination Marketing \& Management, 3(1), 48-58. https://doi.org/10.1016/j.jdmm.2013.12.006

Dobni, D., \& Zinkhan, G. M. (1990). In search of brand image: A foundation analysis. Advances in consumer research, 17(1), 110-119.

Driscoll, A., Lawson, R., \& Niven, B. (1994). Measuring tourists' destination perceptions. Annals of Tourism Research, 21(3), 499-511. https://doi.org/10.1016/0160-7383(94)90117-1

Echtner, C. M. (2002). The content of Third World tourism marketing: a 4A approach. International Journal of Tourism Research, 4(6), 413-434. https://doi.org/10.1002/jtr.401

Echtner, C. M., \& Ritchie, J. B. (1991). The meaning and measurement of destination image. Journal of Tourism Studies, 2(2), 2-12.

Elliot, S., Papadopoulos, N., \& Kim, S.S (2011). An Integrative Model of Place Image: Exploring Relationships between Destination, Product, and Country Images. Journal of Travel Research, 50(5), 520-534. https://doi.org/10.1177/0047287510379161

Ferdinand, N., \& Williams, N. L. (2010). Tourism memorabilia and the tourism experience. In M. Morgan, P. Lugosi, \& J. R. B. Ritchie (Eds.), The tourism and leisure experience: consumer and managerial perspectives (pp. 202-217). Bristol: Channel View.

Gallarza, M. G., Saura, I. G., \& García, H. C. (2002). Destination image: Towards a conceptual framework. Annals of Tourism Research, 29(1), 56-78. https://doi.org/10.1016/S0160-7383(01)00031-7

Gartner, W. C. (1989). Tourism image: attribute measurement of state tourism products using multidimensional scaling techniques. Journal of Travel Research, 28(2), 16-20. https://doi.org/10.1177/004728758902800205 
Gartner, W. C. (1994). Image formation process. Journal of Travel \& Tourism Marketing, 2(2-3), 191-216. https://doi.org/10.1300/J073v02n02_12

Gilbert, D., \& Hudson, S. (2000). Tourism demand constraints: A skiing participation. Annals of Tourism Research, 27(4), 906-925. https://doi.org/10.1016/S0160-7383(99)00110-3

Gladwell, N. J., \& Bedini, L. A. (2004). In search of lost leisure: The impact of caregiving on leisure travel. Tourism Management, 25(6), 685-693. https://doi.org/10.1016/j.tourman.2003.09.003

Go, F. M., \& Govers, R. (2000). Integrated quality management for tourist destinations: a European perspective on achieving competitiveness. Tourism Management, $21(1), \quad$ 79-88. https://doi.org/10.1016/S0261-5177(99)00098-9

Gorsuch, R. L. (1997). Exploratory factor analysis: Its role in item analysis. Journal of Personality Assessment, 68(3), 532-560. https://doi.org/10.1207/s15327752jpa6803_5

Govers, R., Go, F. M., \& Kumar, K. (2007). Promoting tourism destination image. Journal of Travel Research, 46(1), 15-23. https://doi.org/10.1177/0047287507302374

Guo, Y., Seongseop Kim, S., \& Timothy, D. J. (2007). Development characteristics and implications of Mainland Chinese outbound tourism. Asia Pacific Journal of Tourism Research, 12(4), 313-332. http://dx.doi.org/10.1080/10941660701760995

Haugland, S. A., Ness, H., Grønseth, B. O., \& Aarstad, J. (2011). Development of tourism destinations: An integrated multilevel perspective. Annals of Tourism Research, 38(1), 268-290. https://doi.org/10.1016/j.annals.2010.08.008

Hinch, T. D., \& Jackson, E. L. (2000). Leisure constraints research: Its value as a framework for understanding tourism seasonability. Current Issues in Tourism, 3(2), 87-106. https://doi.org/10.1080/13683500008667868

Hsu, S. Y., Dehuang, N., \& Woodside, A. G. (2009). Storytelling research of consumers' self-reports of urban tourism experiences in China. Journal of Business Research, 62(12), 1223-1254. https://doi.org/10.1016/j.jbusres.2008.11.006

Hu, Y., \& Ritchie, J. B. (1993). Measuring destination attractiveness: A contextual approach. Journal of Travel Research, 32(2), 25-34. https://doi.org/10.1177/004728759303200204

Huang, W. J., Chen, C. C., \& Lin, Y. H. (2013). Cultural proximity and intention to visit: Destination image of Taiwan as perceived by Mainland Chinese visitors. Journal of Destination Marketing \& Management, 2(3), 176-184. https://doi.org/10.1016/j.jdmm.2013.06.002

Hung, K., \& Petrick, J. F. (2012). Testing the effects of congruity, travel constraints, and self-efficacy on travel intentions: An alternative decision-making model. Tourism Management, 33(4), 855-867. https://doi.org/10.1016/j.tourman.2011.09.007

Hunt, J. D. (1971). Image: A Factor in Tourism. Quoted in N. Telisman-Kosuta (1989) Tourism Destination Image. In S. F. Witt, \& L. Moutinho (Eds.), Tourism Marketing and Management Handbook (pp. 557-561). Cambridge: Prentice Hall.

Hunt, J. D. (1975). Image as a factor in tourism development. Journal of Travel Research, 13(3), 1-7. https://doi.org/10.1177/004728757501300301

Jackson, E. L. (1988). Leisure constraints: A survey of past research. Leisure Sciences, 10(3), 203-215. https://doi.org/10.1080/01490408809512190

Jackson, E. L., \& Scott, D. (1999). Constraints to leisure. In E. L. Jackson, \& T. L. Burton (Eds.). Leisure Studies: Prospects for the Twenty-first Century (pp. 299-321). State College, PA: Venture Publishing, Inc.

Jani, D., \& Hwang, Y. H. (2011). User-generated destination image through weblogs: A comparison of pre-and post-visit images. Asia Pacific Journal of Tourism Research, 16(3), 339-356. https://doi.org/10.1080/10941665.2011.572670

Jenkins, O. H. (1999). Understanding and measuring tourist destination images. International Journal of Tourism Research, $1(1)$, $1-15$. https://doi.org/10.1002/(SICI)1522-1970(199901/02)1:1\%3C1::AID-JTR143\%3E3.0.CO;2-L

Keller, K. L. (1993). Conceptualizing, measuring, and managing customer-based brand equity. The Journal of Marketing, 1-22. https://doi.org/10.2307/1252054

Kotler, P., \& Gertner, D. (2004). Country as brand, product, and beyond: A place marketing and brand 
management perspective. In N. J. Morgan, A. Pritchard, \& R. Pride (Eds.), Destination Branding: Creating the unique destination proposition (2nd ed., pp. 40-56). Oxford: Elsevier Butterworth-Heinemann.

Kotler, P., Bowen, J. T., Makens, J. C., Xie, Y., \& Liang, C. (2006). Marketing for Hospitality and Tourism (Vol. 893). Upper Saddle River, NJ: Prentice Hall.

Kotler, P., Haider, D. H., \& Rein, I. (1993). Marketing Places. New York, NY: The Free Press.

Kozak, M., \& Rimmington, M. (1999). Measuring tourist destination competitiveness: conceptual considerations and empirical findings. International Journal of Hospitality Management, 18(3), 273-283. https://doi.org/10.1016/S0278-4319(99)00034-1

Lee, B. K., Agarwal, S., \& Kim, H. J. (2012). Influences of travel constraints on the people with disabilities' intention to travel: An application of Seligman's helplessness theory. Tourism Management, 33(3), 569-579. https://doi.org/10.1016/j.tourman.2011.06.011

Li, X. R., \& Stepchenkova, S. (2011). Chinese outbound tourists' destination image of America: Part I. Journal of Travel Research, 51(3), 250-266. https://doi.org/10.1177/0047287511410349

Li, X. R., Harrill, R., Uysal, M., Burnett, T., \& Zhan, X. (2010). Estimating the size of the Chinese outbound travel market: A demand-side approach. Tourism Management, 31(2), 250-259. https://doi.org/10.1016/j.tourman.2009.03.001

Li, Y. (2000). Geographical consciousness and tourism experience. Annals of Tourism Research, 27(4), 863-883. https://doi.org/10.1016/S0160-7383(99)00112-7

Lin, C. T., \& Huang, Y. L. (2009). Mining tourist imagery to construct destination image position model. Expert Systems with Applications, 36(2), 2513-2524. https://doi.org/10.1016/j.eswa.2008.01.074

Llodrà-Riera, I., Martínez-Ruiz, M. P., Jiménez-Zarco, A. I., \& Izquierdo-Yusta, A. (2015). A multidimensional analysis of the information sources construct and its relevance for destination image formation. Tourism Management, 48, 319-328. https://doi.org/10.1016/j.tourman.2014.11.012

Lugosi, P. (2014). Mobilising identity and culture in experience co-creation and venue operation. Tourism Management, 40, 165-179. https://doi.org/10.1016/j.tourman.2013.06.005

MacKay, K. J., \& Fesenmaier, D. R. (2000). An exploration of cross-cultural destination image assessment. Journal of Travel Research, 38(4), 417-423. https://doi.org/10.1177/004728750003800411

Massara, F., \& Severino, F. (2013). Psychological distance in the heritage experience. Annals of Tourism Research, 42, 108-129. https://doi.org/10.1016/j.annals.2013.01.005

Mayo, E. J. (1973). Regional images and regional travel behavior. In The Travel Research Association Fourth Annual Conference Proceedings, 211-218.

McClinchey, K. A., \& Carmichael, B. A. (2010). The role and meaning of place in cultural festival experiences. In M. Morgan, P. Lugosi, \& J. R. B. Ritchie (Eds.), The tourism and leisure experience: consumer and managerial perspectives (pp. 59-77). Bristol: Channel View.

McDougall, G. H., \& Fry, J. N. (1974). Combining two methods of image measurement. Journal of Retailing, 50(4), 53-61.

Miles, M. B., \& Huberman, A. M. (1994). Qualitative Data Analysis (2nd ed.). Thousand Oaks, CA: Sage.

Milman, A., \& Pizam, A. (1995). The role of awareness and familiarity with a destination: The central Florida case. Journal of Travel Research, 33(3), 21-27. https://doi.org/10.1177/004728759503300304

Mok, C., \& Iverson, T. J. (2000). Expenditure-based segmentation: Taiwanese tourists to Guam. Tourism Management, 21(3), 299-305. https://doi.org/10.1016/S0261-5177(99)00060-6

Moscardo, G. (2010). The shaping of tourist experience: the importance of stories and themes. In M. Morgan, P. Lugosi, \& J. R. B. Ritchie (Eds.), The tourism and leisure experience: consumer and managerial perspectives (pp. 43-58). Bristol: Channel View.

Mossberg, L., \& Kleppe, I. A. (2005). Country and destination image-different or similar image concepts?. The Service Industries Journal, 25(4), 493-503. https://doi.org/10.1080/02642060500092147

Murphy, P., Pritchard, M. P., \& Smith, B. (2000). The destination product and its impact on traveller perceptions. Tourism Management, 21, 43-52. https://doi.org/10.1016/S0261-5177(99)00080-1

Nadirova, A., \& Jackson, E. L. (2000). Alternative criterion variables against which to assess the impacts of 
constraints to leisure. Journal of Leisure Research, 32(4), 396.

Nandan, S. (2005). An exploration of the brand identity-brand image linkage: A communications perspective. The Journal of Brand Management, 12(4), 264-278. https://doi.org/10.1057/palgrave.bm.2540222

Neuendorf, K. A. (2001). The Content Analysis Guidebook. London: Sage Publications.

Nyaupane, G. P., \& Andereck, K. L. (2008). Understanding travel constraints: application and extension of a leisure constraints model. Journal of Travel Research, 46(4), 433-439. https://doi.org/10.1177/0047287507308325

Okumus, A., \& Yasin, B. (2008). Examining the Image of Italy, France, and Morocco as a Tourist Destination. In AA.VV., 4th World Conference for Graduate Research in Tourism, Hospitality and Leisure (pp. 12-24), 22-27 April 2008, Antalya, Turkey. Retrieved from http://anatoliajournal.com/atad/depo/bilgibankasi/Kitap_84.pdf

Olsen, J. E., Alexander, J. H., \& Roberts, S. D. (1986). The impact of the visual content of advertisements upon the perceived vacation experience. In Proceedings of the special conference on tourism services marketing presented by the Academy of Marketing Science, and the Marketing Department of Cleveland State University, Cleveland, Ohio, September 24-26, 1986. Cleveland, OH.

Oppermann, M. (2000). Tourism Destination Loyalty. Journal of Travel Research, 39(1), 78-84. https://doi.org/10.1177/004728750003900110

Pan, S., Lee, J., \& Tsai, H. (2014). Travel photos: Motivations, image dimensions, and affective qualities of places. Tourism Management, 40, 59-69. https://doi.org/10.1016/j.tourman.2013.05.007

Papadoupolos, N., Elliot, S., \& De Nisco, A. (2013). From "Made-in" to "Product-country images" and "Place branding": a journey through research time and space. Mercati e competitività, 2, 37-57. https://doi.org/10.3280/MC2013-002003

Pearce, P. L. (1988). The Ulysses Factor. New York, NY: Springer-Verlag. https://doi.org/10.1007/978-1-4612-3924-6

Pike, S. (2002). Destination image analysis-a review of 142 papers from 1973 to 2000. Tourism Management, 23(5), 541-549. https://doi.org/10.1016/S0261-5177(02)00005-5

Pike, S. (2003). The use of repertory grid analysis to elicit salient short-break holiday destination attributes in New Zealand. Journal of Travel Research, 41(3), 315-319. https://doi.org/10.1177/0047287502239054

Pike, S., \& Ryan, C. (2004). Destination positioning analysis through a comparison of cognitive, affective, and conative perceptions. Journal of Travel Research, 42(4), 333-342. https://doi.org/10.1177/0047287504263029

Pikkemaat, B. (2004). The measurement of destination image: the case of Austria. The Poznan University of Economics Review, 4(1), 87-102.

Pizam, A., \& Sussmann, S. (1995). Does nationality affect tourist behavior?. Annals of Tourism Research, 22(4), 901-917. https://doi.org/10.1016/0160-7383(95)00023-5

Poria, Y., Reichel, A., \& Brandt, Y. (2010). The flight experiences of people with disabilities: an exploratory study. Journal of Travel Research, 49(2), 216-227. https://doi.org/10.1177/0047287509336477

Prahalad, C. K., \& Ramaswamy, V. (2004). Co-creation experiences: The next practice in value creation. Journal of Interactive Marketing, 18(3), 5-14. https://doi.org/10.1002/dir.20015

Prebensen, N. K. (2007). Exploring tourists' images of a distant destination. Tourism Management, 28(3), 747-756. https://doi.org/10.1016/j.tourman.2006.05.005

Pudliner, B. A. (2007). Alternative literature and tourist experience: Travel and tourist weblogs. Journal of Tourism and Cultural Change, 5(1), 46-59. https://doi.org/10.2167/jtcc051.0

Qu, H., Kim, L. H., \& Im, H. H. (2011). A model of destination branding: Integrating the concepts of the branding and destination image. Tourism Management, 32(3), 465-476. https://doi.org/10.1016/j.tourman.2010.03.014

Reilly, M. D. (1990). Free elicitation of descriptive adjectives for tourism image assessment. Journal of Travel Research, 28(4), 21-26. https://doi.org/10.1177/004728759002800405

Reynolds, T. J., \& Gutman, J. (1984). Advertising is image management. Journal of Advertising Research, 
24(Feb.), 27-37.

Richter, L. K., \& Waugh, W. L. (1986). Terrorism and tourism as logical companions. Tourism Management, 7(4), 230-238. https://doi.org/10.1016/0261-5177(86)90033-6

Ritchie, J. R. B., \& Ritchie, J. R. R. (1998). The branding of tourism destinations. A Basic Report Prepared for Presentation to the 1998 Annual Congress of the International Association of Scientific Experts in Tourism Marrakech, Morocco, $\quad$ September $1998 . \quad$ Retrieved from https://pdfs.semanticscholar.org/f047/95dd595c0aeb22bf202f6626caac80987644.pdf

Roy, A., Walters, P. G., \& Luk, S. T. (2001). Chinese puzzles and paradoxes: Conducting business research in China. Journal of Business Research, 52(2), 203-210. https://doi.org/10.1016/S0148-2963(99)00071-5

Russell, J. A., \& Pratt, G. (1980). A description of the affective quality attributed to environments. Journal of Personality and Social Psychology, 38(2), 311-322. https://doi.org/10.1037/0022-3514.38.2.311

Ryan, C., \& Aicken, M. (2010). The destination image gap-visitors' and residents' perceptions of place: evidence from Waiheke Island, New Zealand. Current Issues in Tourism, 13(6), 541-561. http://dx.doi.org/10.1080/13683500903215008

Ryan, C., \& Cave, J. (2005). Structuring destination image: A qualitative approach. Journal of Travel Research, 44(2), 143-150. https://doi.org/10.1177/0047287505278991

Ryan, C., \& Michelle Aicken, M. (2010). The destination image gap-visitors' and residents' perceptions of place: evidence from Waiheke Island, New Zealand. Current Issues in Tourism, 13(6), 541-561. https://doi.org/10.1080/13683500903215008

Salazar, N. B. (2012). Tourism imaginaries: A conceptual approach. Annals of Tourism Research, 39(2), 863-882. https://doi.org/10.1016/j.annals.2011.10.004

Scott, D. (1991). The problematic nature of participation in contract bridge: A qualitative study of group — related constraints. Leisure Sciences, 13(4), 321-336. https://doi.org/10.1080/01490409109513148

Sevin, H. E. (2014). Understanding cities through city brands: City branding as a social and semantic network. Cities, 38, 47-56. https://doi.org/10.1016/j.cities.2014.01.003

Shani, A., \& Wang, Y. (2011). Destination image development and communication. Destination Marketing and Management, 130-148. https://doi.org/10.1079/9781845937621.0130

Shinew, K., Floyd, M., \& Parry, D. (2004). Understanding the relationship between race and leisure activities and constraints: exploring an alternative framework. Leisure Sciences, 26(2), 181-199. https://doi.org/10.1080/01490400490432109

Sonmez, S., \& Sirakaya, E. (2002). A distorted destination image? The case of Turkey. Journal of Travel Research, 41(2), 185-196. https://doi.org/10.1177/004728702237418

Stepchenkova, S., \& Morrison, A. M. (2008). Russia's Destination Image among American Pleasure Travelers: Revisiting Echtner and Ritchie. Tourism Management, 29, 548-560. https://doi.org/10.1016/j.tourman.2007.06.003

Tapachai, N., \& Waryszak, R. (2000). An Examination of the Role of Beneficial Image in Tourist Destination Selection. Journal of Travel Research, 39, 37-44. https://doi.org/10.1177/004728750003900105

Tasci, A., Gartner, W., \& Cavusgil, S. T. (2007), Measurement of destination brand bias using a $\begin{array}{llll}\text { quasi-experimental } & \text { design. } & \text { Tourism }\end{array}$ https://doi.org/10.1016/j.tourman.2007.02.009

Tsai, H., Song, H., \& Wong, K. K. (2009). Tourism and hotel competitiveness research. Journal of Travel \& Tourism Marketing, 26(5-6), 522-546. http://dx.doi.org/10.1080/10548400903163079

Tung, V. W. S., \& Ritchie, J. R. B. (2011). Exploring the essence of memorable tourism experiences. Annals of Tourism Research, 38 (4), 1367-1386. https://doi.org/10.1016/j.annals.2011.03.009

Um, S., \& Crompton, J. L. (1999). The roles of image and perceived constraints at different stages in the tourist's destination decision process. In A. Pizam, \& Y. Mansfeld (Eds.), Consumer behavior in travel and tourism (pp. 81-102). New York: Haworth Hospitality Press.

Uysal, M., Chen, J. S., \& Williams, D. R. (2000), Increasing state market share through a regional positioning. Tourism Management, 21, 89-96. https://doi.org/10.1016/S0261-5177(99)00082-5 
Veasna, S., Wu, W. Y., \& Huang, C. H. (2013). The impact of destination source credibility on destination satisfaction: The mediating effects of destination attachment and destination image. Tourism Management, 36, 511-526. https://doi.org/10.1016/j.tourman.2012.09.007

Wang, Y., Yu, Q., \& Fesenmaier, D. R. (2002). Defining the virtual tourist community: implications for tourism marketing. Tourism Management, 23(4), 407-417. https://doi.org/10.1016/S0261-5177(01)00093-0

Watson, P., Morgan, M., \& Hemmington, N. (2008). Online communities and the sharing of extraordinary $\begin{array}{llll}\text { restaurant } & \text { experiences. Journal of 289-302. }\end{array}$ https://doi.org/10.1111/j.1748-0159.2008.00110.x

Weber, R. P. (1990). Basic content analysis (2nd ed.). Newbury Park, CA: Sage. https://doi.org/10.4135/9781412983488

Weinberger, M. G., Allen, C. T., \& Dillon, W. R. (1981). Negative information: perspectives and research directions. In B. Monroe e A. Abor (Eds.), Advances in Consumer Research, 8, 398-404.

Williams, E., \& Clarke, T. (1991). Country image-as others see us. In Seminar on travel and tourism in transition: the research challenge, Dublin (Ireland) 29th-31st May 1991. (pp. 159-173). European Society for Opinion and Marketing Research (ESOMAR).

Woelfel, J. (1993). Artificial neural networks in policy research: A current assessment. Journal of Communication, 43(1), 63-80. https://doi.org/10.1111/j.1460-2466.1993.tb01249.x

$\mathrm{Xu}, \mathrm{Y} .$, \& McGehee, N. G. (2012). Shopping behaviour of Chinese tourists visiting the United States. Letting the shoppers do the talking. Tourism Management, 33, 427-430. https://doi.org/10.1016/j.tourman.2011.05.003

Yeoman, I., Brass, D., \& McMahon-Beattie, U. (2007). Current issue in tourism: The authentic tourist. Tourism Management, 28, 1128-1138. https://doi.org/10.1016/j.tourman.2006.09.012

Yoo, B., \& Donthu, N. (2001). Developing \& validating a multidimensional consumer based brand equity scale. Journal of Business Research, 52, 1-14. https://doi.org/10.1016/S0148-2963(99)00098-3

Zeithaml, V. A., Berry, L., \& Parasuraman, A. (1996). The Behavioral Consequences of Service Quality. Journal of Marketing, 60, 31-46. https://doi.org/10.2307/1251929

Zenker, S., \& Beckmann, S. C. (2013). My place is not your place — different place brand knowledge by different target groups. Journal of Place Management and Development, 6(1), 6-17. https://doi.org/10.1108/17538331311306078

Zenker, S., \& Braun, E. (2010). Branding a City-A Conceptual Approach for Place Branding and Place Brand Management. Paper presented at the 39th European Marketing Academy Conference, Copenhagen, Denmark. $\quad$ Retrieved http://www.placebrand.eu/mediapool/85/857874/data/Zenker_Braun_EMAC2010.pdf

Zube, E., \& Pitt, D. (1981). Cross-cultural perceptions of scenic and heritage landscapes. Landscape Planning, 8(1), 69-87. https://doi.org/10.1016/0304-3924(81)90041-1

\section{Notes}

Note 1. Often translated as "face", mianzi is the recognition of an individual's role in society. The concept of mianzi is one of the most delicate principles regulating interpersonal relationships among Chinese, implying a set of values including reputation and social status, dignity, prestige, credibility and respect.

Note 2. In Chinese, the word "guanxi" has multiple meanings: it indicates a relationship, a bond, importance, meaning, friendship or, more generally, the social community (or the community of those with similar interests) to which an individual belongs. It is characterised by a highly reticular structure, where the various "nodes" cooperate and support each other, often exchanging favours. It is guanxi that minimises obstacles and risk, and it is through guanxi that problems are resolved. "Guanxi" is a vital part of the heritage that a person accumulates over their lifetime, because it is non-extemporaneous, based on knowledge, reciprocity, loyalty, the acquisition and consolidation of trust over time: to become part of a guanxi it is necessary to demonstrate one's reliability and respect (for people and promises made), while to be expelled from one, it is sufficient to behave oneself in an unacceptable way, for example not repaying a favour, only once.

Note 3. For a Chinese tourist, the hotel represents more than just a place to sleep: it is the mirror of the host country, the first place of contact with its culture and lifestyle. 


\section{Copyrights}

Copyright for this article is retained by the author, with first publication rights granted to the journal.

This is an open-access article distributed under the terms and conditions of the Creative Commons Attribution license (http://creativecommons.org/licenses/by/4.0/). 